\title{
Early mixing and mingling in the evolution of basaltic magmas: evidence from phenocryst assemblages, Slamet Volcano, Java, Indonesia
}

\author{
O. Reubi ${ }^{\mathrm{a}, *}$, I.A. Nicholls ${ }^{\mathrm{a}}$, V.S. Kamenetsky ${ }^{\mathrm{b}}$ \\ a Victorian Institute of Earth and Planetary Sciences, School of Geosciences, Monash University, Melbourne, Vic. 3800, Australia \\ b School of Earth Sciences and Centre for Ore Deposit Research, University of Tasmania, GPO Box 252-79, Hobart, \\ Tasmania 7001, Australia
}

Received 10 December 2001; accepted 2 May 2002

\begin{abstract}
Slamet Volcano, in Central Java, Indonesia, is an active calc-alkaline stratovolcano composed largely of basalts and basaltic andesites. The phenocryst mineralogy of the most magnesian basalts $(\mathrm{MgO}>7 \mathrm{wt} \%)$ has been studied in detail to investigate the nature of early magmatic processes in a large arc volcano. On the basis of stratigraphy, mineralogy, petrography and geochemistry, the studied basalts are subdivided in two groups; Old Slamet (OS) and New Slamet (NS). Olivine in the OS basalts is within the range Fog $_{2-65}$ and shows a homogenous composition distribution, with a significant proportion of crystal cores near equilibrium with whole-rock compositions. However, distinct high- and low-Ni sub-populations may be distinguished at any given Fo content (e.g. $0.25-0.10 \%$ and 0.32 $0.27 \mathrm{wt} \% \mathrm{NiO}$ for the low- and high-NiO sub-populations respectively at $\left.\mathrm{Fo}_{85}\right)$. Chromian spinel inclusions within the high- $\mathrm{NiO}$ olivines have higher $\mathrm{Cr} \#(75-80)$ and $\mathrm{Fe}^{2+} / \mathrm{Fe}^{3+}$ ratio (2.6-3.2) and lower $\mathrm{TiO}_{2}(0.23-0.44 \mathrm{wt} \%)$ contents than those within low-NiO olivines $\left(\mathrm{Cr} \# 58-77, \mathrm{Fe}^{2+} / \mathrm{Fe}^{3+} 1.3-2.5\right.$ and $\left.\mathrm{TiO}_{2} \quad 0.73-0.91 \mathrm{wt} \%\right)$. Plagioclase and pyroxene phenocrysts display dominantly oscillatory zoning, with cores close to equilibrium with whole-rock compositions. Olivine in the NS basalts is within the range $\mathrm{Fo}_{90-61}$ and shows a discontinuous distribution of composition including two principal peaks: the first is $\sim \mathrm{Fo}_{78-90}$, close to expected equilibrium compositions; the second is $\sim \mathrm{Fo}_{62-70}$, clearly too Fe-rich to be in equilibrium with whole-rock compositions and composed mainly of reversely zoned crystals. In terms of $\mathrm{NiO}$ content, a single (low-Ni) sub-population is observed. Chromian spinel inclusions with high $\mathrm{Cr} \#$ and $\mathrm{Fe}^{2+} / \mathrm{Fe}^{3+}$ ratio and low $\mathrm{TiO}_{2}$ are not observed within the olivines of these basalts. Plagioclase and pyroxene phenocrysts are typically reversely zoned and display ubiquitous disequilibrium textures. The cores of these crystals are not in equilibrium with host basalt compositions. The mineralogy of these basalts indicates that the OS basalts resulted from mixing between two parental magmas produced from contrasted sources, probably a relatively depleted and $\mathrm{H}_{2} \mathrm{O}$-poor harzburgite and a less depleted and more hydrated harzburgite to lherzolite. Subsequent evolution occurred in a magmatic system in which variations in volatile contents and/or temperature played a more important role than magma mixing. The NS basalts were produced from the less depleted source only, but magmas interacted extensively with remnants of earlier crystal mush/magma batches. Open-system processes operated early in the life of all these magmas, and influenced their geochemistry. Magma mixing was a
\end{abstract}

\footnotetext{
* Corresponding author. Fax: +61-3-9905-4903.

E-mail address: oreubi@mail.earth.monash.edu.au (O. Reubi).
} 
ubiquitous process and together with fractional crystallisation controlled the evolution of the basaltic magmas of Slamet Volcano.

(C) 2002 Elsevier Science B.V. All rights reserved.

Keywords: basalts; Sunda Arc; olivine; magma mixing; spinel

\section{Introduction}

Subduction zone volcanism is one of the dominant forms of volcanism on Earth and is believed to be the major producer of continental crust. Consequently, understanding arc volcanism is critical to our comprehension of fundamental geological problems such as the formation and growth of the continents and predicting volcanic hazards. Arc magmas encompass a broad spectrum of compositions, which essentially reflects the complexity of their sources and the variability of composition-modifying processes that occur during their ascent through the lithosphere. A consensus has emerged on the origin of arc magmas from the mantle wedge, modified by a subduction-related component(s) (e.g. Arculus, 1994; Pearce and Peate, 1995). However, identifying the exact nature and composition of the pristine mantle wedge and of the slab-derived agent, as well as establishing the degree of interaction between these two components and their respective impact on the magmatic evolution for a specific volcano, remain problematic. This is largely due to the scarcity of near-primary magma compositions in arc volcanoes. Therefore, recognising the processes that modify the composition of primary magmas is often a prerequisite in order to understand the genesis and evolution of subduction-related magmas.

Several recent studies conducted on arc lavas have pointed to the importance of open-system processes, in particular magma mixing/mingling, in the evolution of arc magmas (e.g. Singer et al., 1995; Feeley and Dungan, 1996; Gamble et al., 1999; Tepley et al., 2000; Dungan et al., 2001). Injection of mafic magma into more silicic magma chambers appears to be a very common if not ubiquitous process. It is often regarded as the eruption triggering mechanism and may also play an important role in magmatic evolution. Some authors have suggested that magmatic evolution in arc volcanoes occurs mainly within plumbing systems, where constant interaction between fresh magma and stagnant melt or/and crystal mush accumulated in several small reservoirs predominates (e.g. Gamble et al., 1999; Dungan et al., 2001). However, these models are essentially based upon studies carried out on intermediate compositions and the extent to which processes such as magma mixing/mingling affect relatively mafic magmas at arc volcanoes remains poorly constrained.

Slamet Volcano, in Central Java, Indonesia, is an unusual calc-alkaline volcano as it contains a high proportion of basalts, which occasionally contain olivines as magnesian as $\mathrm{Fo}_{92}$ (Whitford, 1975; Vukadinovic, 1989). Despite an apparently simple tectonic setting, Slamet basalts show a wide range of phenocryst compositions (Vukadinovic, 1989), which suggests that they are the products of diverse and variable magmatic processes. In this paper we present a detailed study of the mineralogy of the four most magnesian $(\mathrm{MgO}>7 \mathrm{wt} \%)$ basalts analysed by Vukadinovic (1989). The aim is to document the early magmatic processes that affect relatively mafic magmas and to evaluate their broader implications for magmatic evolution in this large arc volcano.

\section{Geological setting and geochemistry of Slamet Volcano}

The Quaternary, $3428 \mathrm{~m}$ high Slamet Volcano is situated in Central Java, Indonesia (Fig. 1). It belongs to the Sunda arc system that formed as a result of the northward subduction of the IndoAustralian plate beneath the Eurasian plate (Hamilton, 1979). The volcanic edifice is built upon $20-25 \mathrm{~km}$ thick continental crust with an 


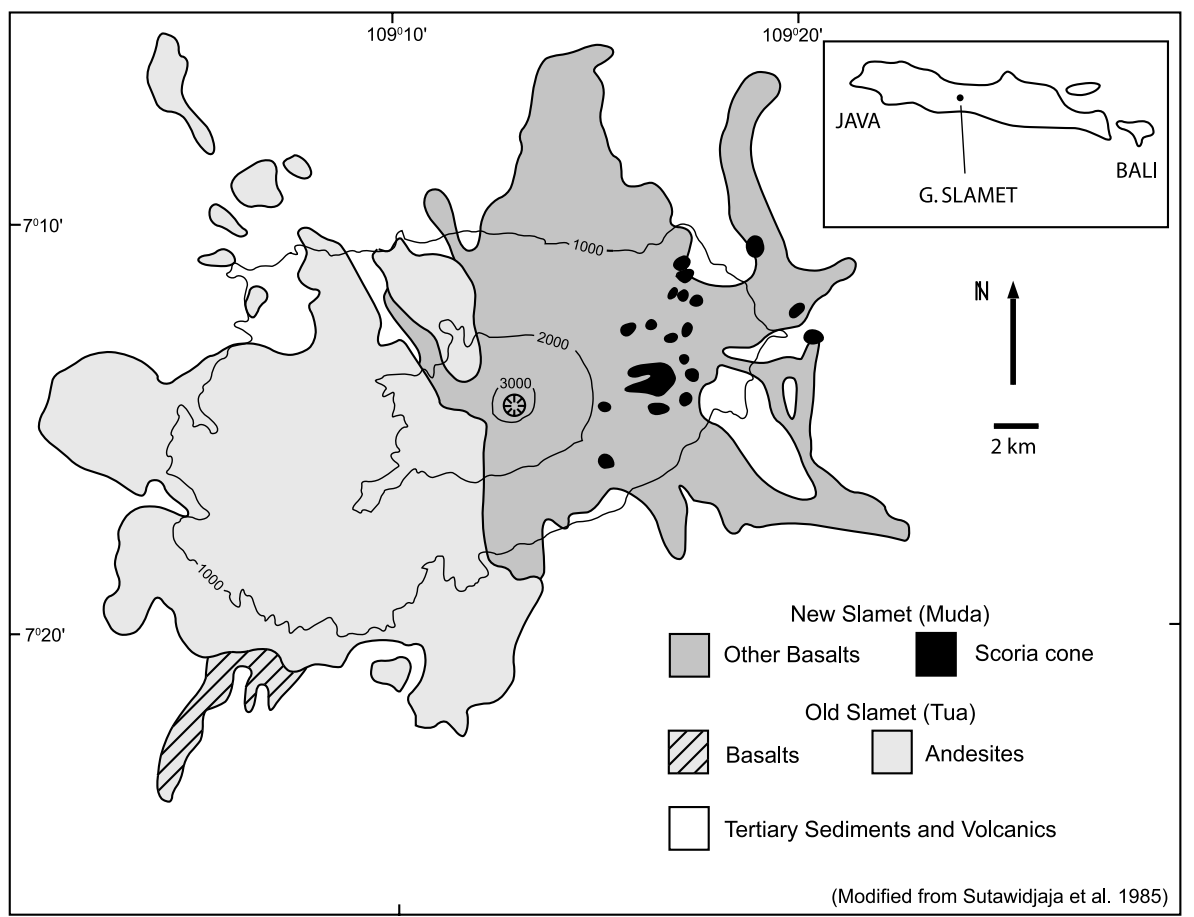

Fig. 1. Geological map of Slamet Volcano (after Sutawidjaja et al., 1985; Vukadinovic, 1989).

intermediate velocity structure (Curray et al., 1982). The complex includes the products of two overlapping stratocones (Fig. 1): Old Slamet (OS) and New Slamet (NS). OS is characterised by a rough topography, consisting of deep valleys, plateaux and peaks, and is composed dominantly of basaltic andesites and andesites. NS shows a smoother topography, disrupted only by a field of 35 scoria cones on its flanks. It is composed entirely of basalts and basaltic andesites. The products of the two stratocones with few exceptions show distinctions in mineralogy and geochemistry sufficient to allow them to be recognised as the OS and NS groups.

Slamet lavas show a continuous range of composition from basalt $\left(49 \mathrm{wt} \% \mathrm{SiO}_{2}\right)$ to dacite (64 $\mathrm{wt} \% \mathrm{SiO}_{2}$ ). They are calc-alkaline to high-K calcalkaline in nature (classification of Peccerillo and Taylor, 1976), but differ from 'typical' calc-alkaline lavas in containing relatively high concentrations of $\mathrm{TiO}_{2}(1.05-1.8 \mathrm{wt} \%$ ) (Whitford, 1975; Vukadinovic, 1989; Vukadinovic and Nicholls, 1989). The OS rocks are more felsic, have higher
$\mathrm{Zr} / \mathrm{Nb}$ and ${ }^{87} \mathrm{Sr} /{ }^{86} \mathrm{Sr}$ ratios, lower rare earth element (REE), especially light REE (LREE), abundances, and lower $\mathrm{Nb} / \mathrm{U}$ and $\mathrm{Zr} / \mathrm{K}$ ratios than $\mathrm{NS}$ rocks (Vukadinovic, 1989; Vukadinovic and Nicholls, 1989).

The four selected samples are basaltic in composition, with $\mathrm{SiO}_{2}$ contents between 50.1 and $50.7 \mathrm{wt} \%$ and $\mathrm{MgO}$ contents between 7.1 and $7.7 \mathrm{wt}^{\%} \%$ (Table 1). Two samples belong to the OS group (S154 and S30) and two to the NS group (S108 and S222). These samples have typical subduction-related trace element features (Fig. 2; Table 2). Large ion lithophile elements (LILE) are enriched relative to LREE (Ba/La 14-18) and both groups are enriched relative to high field strength elements (HFSE) (Ba/Nb 22 $35 ; \mathrm{La} / \mathrm{Nb}$ 1.5-2). HFSE abundances are high compared to N-MORB values: e.g. $\mathrm{Nb} / \mathrm{Yb}=$ 2.7-4, compared with 0.8 for average N-MORB (Sun and McDonough, 1989). The two OS basalts have lower HFSE abundances and $\mathrm{Nb} / \mathrm{Yb}$ ratios and similar LILE abundances compared with the two NS basalts (Fig. 2). 
Table 1

Major element data and modal analyses of Slamet basalts

\begin{tabular}{|c|c|c|c|c|}
\hline & \multicolumn{2}{|c|}{ Old Slamet } & \multicolumn{2}{|c|}{ New Slamet } \\
\hline & $\mathrm{S} 30$ & $\mathrm{~S} 154$ & $\mathrm{~S} 222$ & $\mathrm{~S} 108$ \\
\hline $\mathrm{SiO}_{2}$ & 50.60 & 50.12 & 50.53 & 50.73 \\
\hline $\mathrm{TiO}_{2}$ & 1.15 & 1.11 & 1.20 & 1.25 \\
\hline $\mathrm{Al}_{2} \mathrm{O}_{3}$ & 17.01 & 16.36 & 16.02 & 15.74 \\
\hline $\mathrm{FeO}^{*}$ & 9.45 & 10.13 & 9.95 & 10.11 \\
\hline $\mathrm{MnO}$ & 0.18 & 0.19 & 0.19 & 0.19 \\
\hline $\mathrm{MgO}$ & 7.07 & 7.69 & 7.49 & 7.70 \\
\hline $\mathrm{CaO}$ & 10.36 & 10.46 & 10.35 & 10.46 \\
\hline $\mathrm{Na}_{2} \mathrm{O}$ & 3.03 & 2.97 & 2.96 & 2.66 \\
\hline $\mathrm{K}_{2} \mathrm{O}$ & 0.99 & 0.89 & 1.11 & 1.00 \\
\hline Total & 99.84 & 99.92 & 99.80 & 99.84 \\
\hline $\mathrm{mg \#}$ & 57.1 & 57.5 & 57.3 & 57.6 \\
\hline Oliv & 8 & 7 & 4.5 & 6 \\
\hline $\mathrm{Cpx}$ & 5 & 5 & 6 & 15 \\
\hline Opx & 0 & 0 & $<1$ & $<1$ \\
\hline Plag & 20 & 22 & $<1$ & 2 \\
\hline Fe-oxide & $<1$ & $<1$ & $<1$ & $<1$ \\
\hline Total pheno & 33 & 34 & 11 & 23 \\
\hline
\end{tabular}

Major element data from Vukadinovic (1989).

\section{Analytical methods}

Olivine analyses were obtained on separated grains. The samples were crushed and sieved. Ol- ivine grains were then hand-picked from the crushed material, mounted in epoxy and polished to expose their cores. Pyroxene and plagioclase analyses were obtained on polished thin sections of their host rocks. Mineral analyses were conducted on Cameca SX-50 microprobes at Melbourne University and the University of Tasmania. The accelerating voltage used in each case was $15 \mathrm{kV}$ and the beam current $25 \mathrm{nA}$. Counting times were $10 \mathrm{~s}$ for major elements and $30 \mathrm{~s}$ for minor elements. Analytical uncertainty is mostly $<1 \%$ for major elements and around $10-15 \%$ for trace elements. Whole-rock trace elements were determined by inductively coupled plasma-mass spectrometry on a Finnigan-MAT ELEMENT at Monash University. Samples were dissolved by $\mathrm{HF}-\mathrm{HNO}_{3}, \mathrm{HNO}_{3}$ and $\mathrm{HCl}$ acid digestion. Precision is typically better than $\pm 2.5 \%$.

\section{Petrography}

The four studied basalts are black to grey, porphyritic and non-vesicular to moderately vesicular (up to $10 \%$ ). In thin section, all have microlitic to microgranular textures, with olivine, clinopyrox-

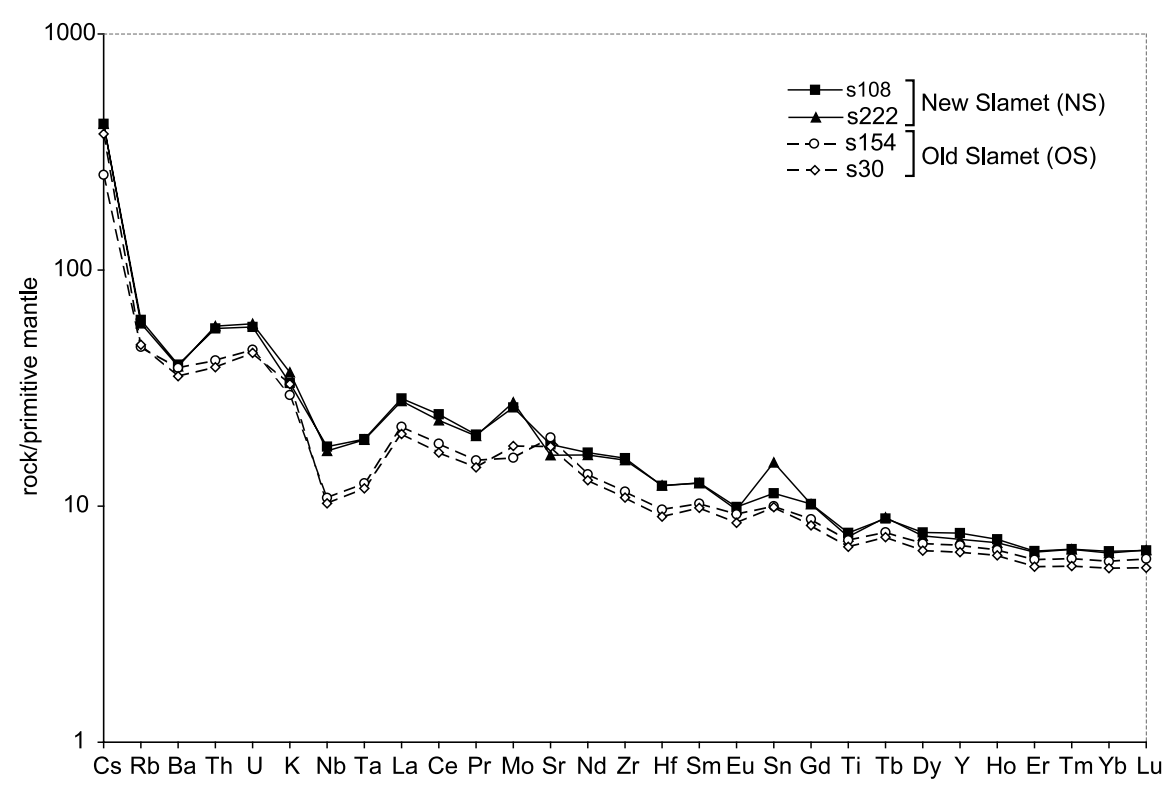

Fig. 2. Primitive mantle normalised trace element patterns for the Slamet basalts (normalising values from Sun and McDonough, 1989). 
Table 2

Trace element data of Slamet basalts

\begin{tabular}{|c|c|c|c|c|}
\hline \multirow[t]{2}{*}{ Sample } & \multicolumn{2}{|c|}{ Old Slamet } & \multicolumn{2}{|c|}{ New Slamet } \\
\hline & $\mathrm{S} 30$ & S154 & S222 & S108 \\
\hline $\mathrm{Sc}$ & 38.7 & 43.6 & 41.0 & 40.8 \\
\hline $\mathrm{V}$ & 340 & 365 & 318 & 318 \\
\hline $\mathrm{Cr}$ & 189 & 192 & 252 & 256 \\
\hline $\mathrm{Mn}$ & 1589 & 1693 & 1698 & 1719 \\
\hline Co & 42.5 & 46.2 & 41.5 & 44.8 \\
\hline $\mathrm{Ni}$ & 64.2 & 69.6 & 59.9 & 63.6 \\
\hline $\mathrm{Cu}$ & 116 & 117 & 124 & 164 \\
\hline $\mathrm{Zn}$ & 86 & 93 & 119 & 100 \\
\hline $\mathrm{Ga}$ & 25.8 & 27.7 & 26.5 & 26.9 \\
\hline $\mathrm{Rb}$ & 30.7 & 30.0 & 37.7 & 39.0 \\
\hline $\mathrm{Sr}$ & 377 & 412 & 347 & 385 \\
\hline $\mathrm{Y}$ & 29.0 & 31.0 & 32.9 & 35.0 \\
\hline $\mathrm{Zr}$ & 122 & 129 & 175 & 179 \\
\hline $\mathrm{Nb}$ & 7.3 & 7.7 & 12.2 & 12.7 \\
\hline Mo & 1.13 & 1.01 & 1.73 & 1.65 \\
\hline $\mathrm{Sn}$ & 1.68 & 1.70 & 2.60 & 1.93 \\
\hline Cs & 2.98 & 2.00 & 3.29 & 3.28 \\
\hline $\mathrm{Ba}$ & 248 & 269 & 273 & 277 \\
\hline $\mathrm{La}$ & 13.9 & 14.9 & 19.1 & 19.6 \\
\hline $\mathrm{Ce}$ & 29.9 & 32.7 & 41.0 & 43.4 \\
\hline $\operatorname{Pr}$ & 4.03 & 4.31 & 5.47 & 5.55 \\
\hline $\mathrm{Nd}$ & 17.4 & 18.5 & 22.3 & 22.8 \\
\hline $\mathrm{Sm}$ & 4.37 & 4.56 & 5.55 & 5.58 \\
\hline $\mathrm{Eu}$ & 1.43 & 1.55 & 1.62 & 1.66 \\
\hline $\mathrm{Gd}$ & 4.94 & 5.25 & 6.08 & 6.08 \\
\hline $\mathrm{Tb}$ & 0.798 & 0.837 & 0.968 & 0.956 \\
\hline Dy & 4.78 & 5.12 & 5.52 & 5.70 \\
\hline Ho & 1.02 & 1.07 & 1.15 & 1.19 \\
\hline $\mathrm{Er}$ & 2.66 & 2.85 & 3.07 & 3.09 \\
\hline $\mathrm{Tm}$ & 0.413 & 0.444 & 0.485 & 0.486 \\
\hline $\mathrm{Yb}$ & 2.69 & 2.88 & 3.12 & 3.17 \\
\hline $\mathrm{Lu}$ & 0.405 & 0.443 & 0.482 & 0.480 \\
\hline $\mathrm{Hf}$ & 2.79 & 2.99 & 3.78 & 3.77 \\
\hline $\mathrm{Ta}$ & 0.487 & 0.513 & 0.783 & 0.788 \\
\hline $\mathrm{Pb}$ & 14.1 & 12.3 & 51.7 & 15.3 \\
\hline Th & 3.29 & 3.52 & 4.92 & 4.81 \\
\hline $\mathrm{U}$ & 0.935 & 0.965 & 1.24 & 1.21 \\
\hline
\end{tabular}

All elements analysed by inductively coupled plasma-mass spectrometry.

ene, plagioclase \pm orthopyroxene as phenocrysts and $\mathrm{Ti}$-magnetite as micro-phenocrysts.

In the two OS samples (S154 and S30), total phenocryst contents are $32-34 \%$ (determined by point counting) and plagioclase (19-22\%) is more abundant than olivine (7-8\%) and $\mathrm{Ca}-$-clinopyroxene (4-5\%) (Table 1). Two types of olivine grains are observed (Table 3): Type 1 olivines are relatively rich in inclusions of $\mathrm{Cr}$-spinel and con- tain occasional tiny melt inclusions (Fig. 3a); Type 2 olivines display a core rich in small (10 $50 \mu \mathrm{m})$ melt inclusions and contain occasional $\mathrm{Ti}-$ magnetite inclusions (Fig. 3b). Type 2 olivine represents about $15 \%$ of OS olivine. Clinopyroxene grains are euhedral to subhedral and show slight oscillatory zoning under crossed polars. Cpx commonly occurs in crystal clots with olivine. Plagioclase is euhedral, with extensive multiple concentric sieve-textured zones containing abundant glass inclusions separated by clear zones with oscillatory zoning. The groundmass consists of microlites of plagioclase, clinopyroxene, olivine, titanomagnetite, cryptocrystalline material, and interstitial glass.

The NS samples contain $11-23 \%$ phenocrysts, with $\mathrm{Ca}$-clinopyroxene the dominant phase (6$16 \%)$, followed by olivine (5-6\%) and plagioclase $(0.5-2 \%)$ (Table 1$)$. Three distinct olivine types are observed (Table 3): Types 1 and 2 are similar to those types in OS basalts (respectively $10-50 \%$ and $20-40 \%$ of NS olivine). Type 3 olivines have a clear core mantled by a spongy rim (Fig. 3c) and form $20-50 \%$ of NS olivine. Clinopyroxene is euhedral and generally displays either a resorbed core or a concentric zone of resorption mantled by a clear rim. Clinopyroxenes with weak oscillatory zoning are also occasionally observed. Plagioclase when present as phenocrysts shows intensively resorbed cores mantled by clear rims. Orthopyroxene is mantled by clinopyroxene. The groundmass consists of microlitic plagioclase, clinopyroxene, olivine, Ti-magnetite, cryptocrystalline material and interstitial glass.

\section{Mineral chemistry}

\subsection{Olivine}

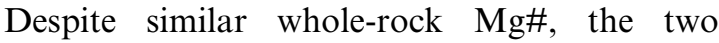
groups of basalts contain distinct olivine composition ranges and distributions. Fig. 4 shows histograms of olivine core compositions for the four analysed basalts. Olivine in the OS basalts ranges in composition from $\mathrm{Fo}_{92}$ to $\mathrm{Fo}_{65}$ (Fig. 4a,b; Table 4), showing a broad continuous distribution 
a) Type 1 (OS and NS basalts)

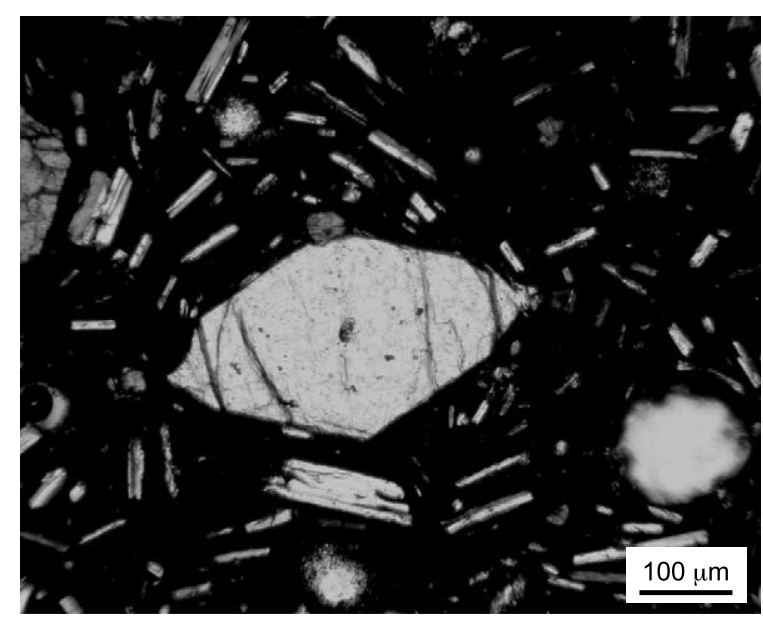

c) Type 3 (NS basalts)

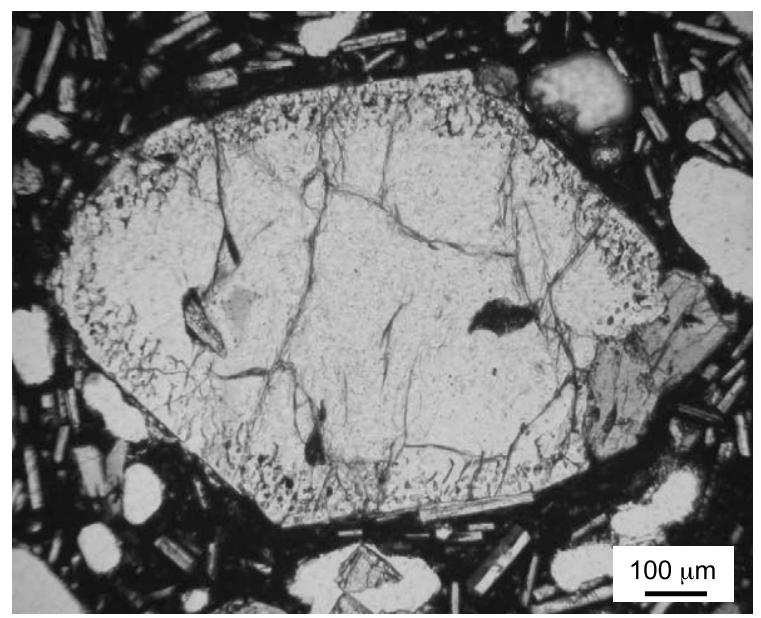

\section{b) Type 2 (OS and NS basalts)}

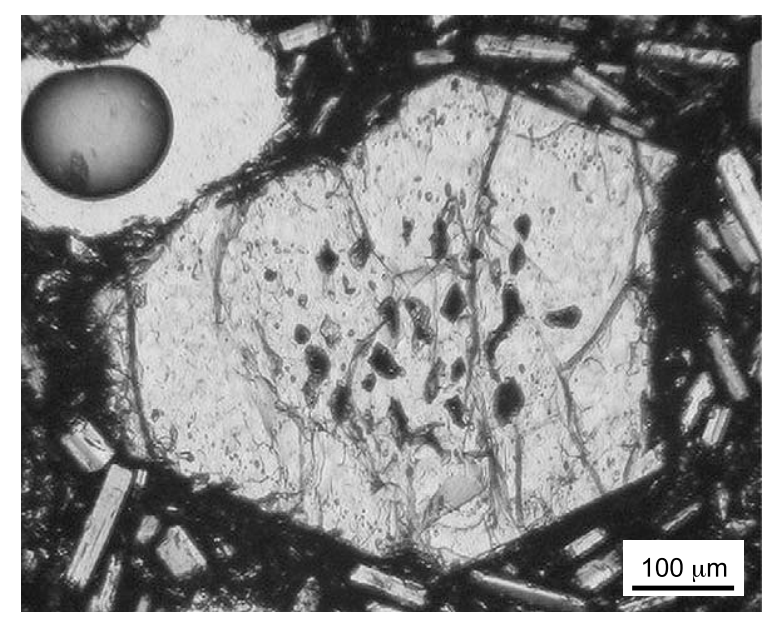

Fig. 3. Photomicrographs of olivine phenocrysts. (a) Crystal with a clear core from the sample S30 (OS). (b) Crystal with a core full of melt inclusions from the sample S30 (OS). (c) Crystal with a spongy border from the sample S222 (NS).

Table 3

Summary of the principal petrographic and mineralogical features of the olivines

\begin{tabular}{|c|c|c|}
\hline Olivine type & Old Slamet basalts & New Slamet basalts \\
\hline Type 1 & $\begin{array}{l}\text { euhedral, clear, } \mathrm{Cr}-\text {-spinel inclusions, normally } \\
\text { zoned, broad core } \text { Fo }_{92-80} \text { narrow rim } \text { Fo }_{85-65}\end{array}$ & $\begin{array}{l}\text { euhedral, clear, Cr-spinel inclusions, normally zoned, broad } \\
\text { core } \text { Fog }_{92-78} \text { narrow rim } \text { Fo }_{85-65}\end{array}$ \\
\hline Type 2 & $\begin{array}{l}\text { core rich in melt inclusions, titanomagnetite } \\
\text { inclusions, normally zoned, core } \mathrm{Fo}_{75-72} \text {, } \\
\text { rim } \mathrm{Fo}_{68-65}\end{array}$ & $\begin{array}{l}\text { core rich in melt inclusions, titanomagnetite inclusions, } \\
\text { normally zoned core } \mathrm{Fo}_{75-65} \text {, reversely zoned rim } \mathrm{Fo}_{70-80}\end{array}$ \\
\hline Type 3 & & $\begin{array}{l}\text { melt inclusion-rich (spongy) rim, reversely zoned, core } \\
\mathrm{Fo}_{75-65} \text {, rim } \mathrm{Fo}_{65-80}\end{array}$ \\
\hline
\end{tabular}


(Fig. 4a,b). Olivine in the NS basalts ranges in composition from $\mathrm{Fo}_{90}$ to $\mathrm{Fo}_{61}$ (Fig. 4c,d; Table 4). S222 shows a continuous range of composition with a significant peak around $\mathrm{Fo}_{81}$. S108 displays a discontinuous distribution with a small peak at $\mathrm{Fo}_{85}$ and a major one at around $\mathrm{Fo}_{65}$.

The calculated range of olivine compositions in equilibrium with the observed range of wholerock $\mathrm{Mg \#}$, using ${ }^{\mathrm{Fe} / \mathrm{Mg}} K_{\mathrm{D} \text { min/liq }} 0.29-0.34$ (Roeder and Emslie, 1970), is Fo82-84.5. Distributions of olivine composition in the two OS samples are centred near the expected equilibrium compositions (Fig. 4a,b), which suggests that the majority of these olivines have crystallised in a melt similar to the host whole-rock composition in terms of

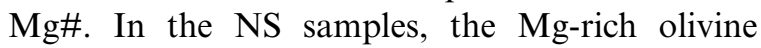
peaks have compositions close to the calculated equilibrium olivine (Fig. 4c,d). The low-Fo olivines are clearly not in equilibrium with liquids similar to the whole-rock compositions, indicating that they represent coarse crystals mechanically incorporated into more mafic liquids.

In the four studied samples, Type 1 olivines are strongly normally zoned, typically $\mathrm{Fo}_{80-65}$ (Fig. 5a,c; Table 3). Type 2 olivines in OS basalts are also normally zoned, $\mathrm{Fo}_{75-65}$ (Fig. 5b), whereas those in NS basalts have normally zoned cores, $\mathrm{Fo}_{75-65}$, surrounded by reversely zoned rims, $\mathrm{Fo}_{70-80}$, (Fig. 5d). Type 3 olivines in NS samples have normally zoned cores, $\mathrm{Fo}_{75-65}$, mantled by reversely zoned rims, $\mathrm{Fo}_{65-80}$ (Fig. 5e). The cores of reversely zoned Type 2 and 3 olivines in NS basalts form the low-Fo peaks described earlier, consistent with the interpretation that they formed in more evolved melt.

In Fig. 6, the $\mathrm{NiO}$ content of olivine is plotted against Fo content. Two distinct high- and low-Ni populations may be distinguished amongst olivines with $\mathrm{Fo} \%>80$. These two populations have similar ranges of $\mathrm{NiO}$ contents (up to 0.42 $\mathrm{wt} \%$ ) but different $\mathrm{NiO}$ contents at any given $\mathrm{Fo}$ content (e.g. $0.25-0.10 \%$ and $0.32-0.27 \mathrm{wt} \% \mathrm{NiO}$ for the high- and low-NiO populations respectively at $\mathrm{Fo}_{85}$ ). The low-NiO population is also characterised by higher maximum Fo content (up to $\mathrm{Fo}_{92}$ ). It includes olivines from both $\mathrm{OS}$
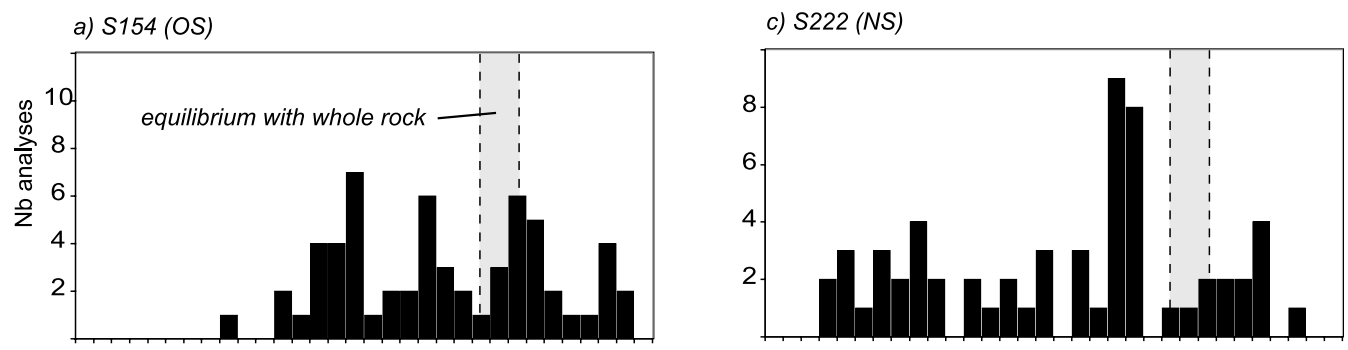

\section{b) $S 30$ (OS)}
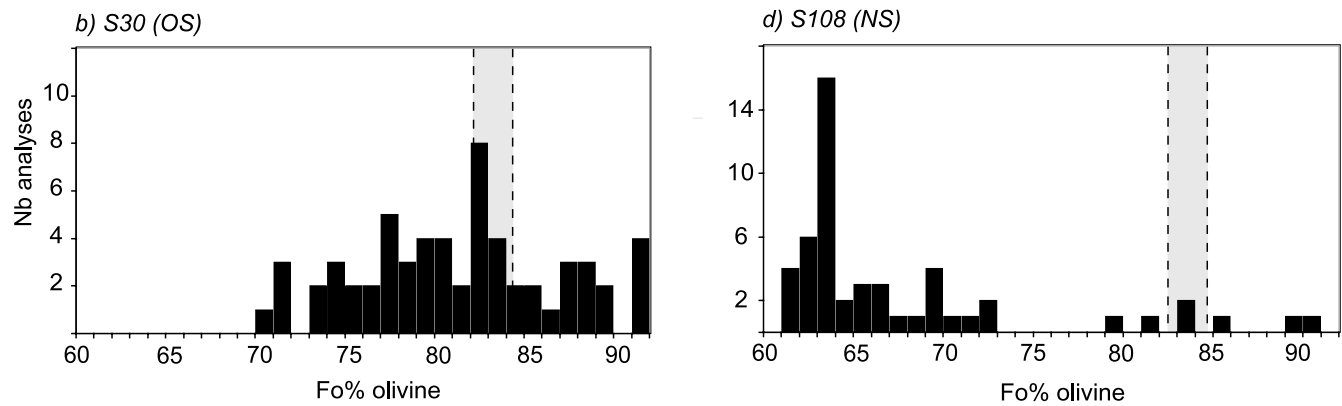

Fig. 4. Histograms showing the $\mathrm{Fo}_{\%} \%$ distribution of olivine for the four studied basalts. Arrows mark the average compositions. Ranges of composition in equilibrium with each whole-rock composition have been calculated using ${ }^{\mathrm{Fe} / \mathrm{Mg}} K_{\mathrm{D} \text { min/liq }}$ values of 0.29-0.34 (Roeder and Emslie, 1970; Ulmer, 1989; Sisson and Grove, 1993). 

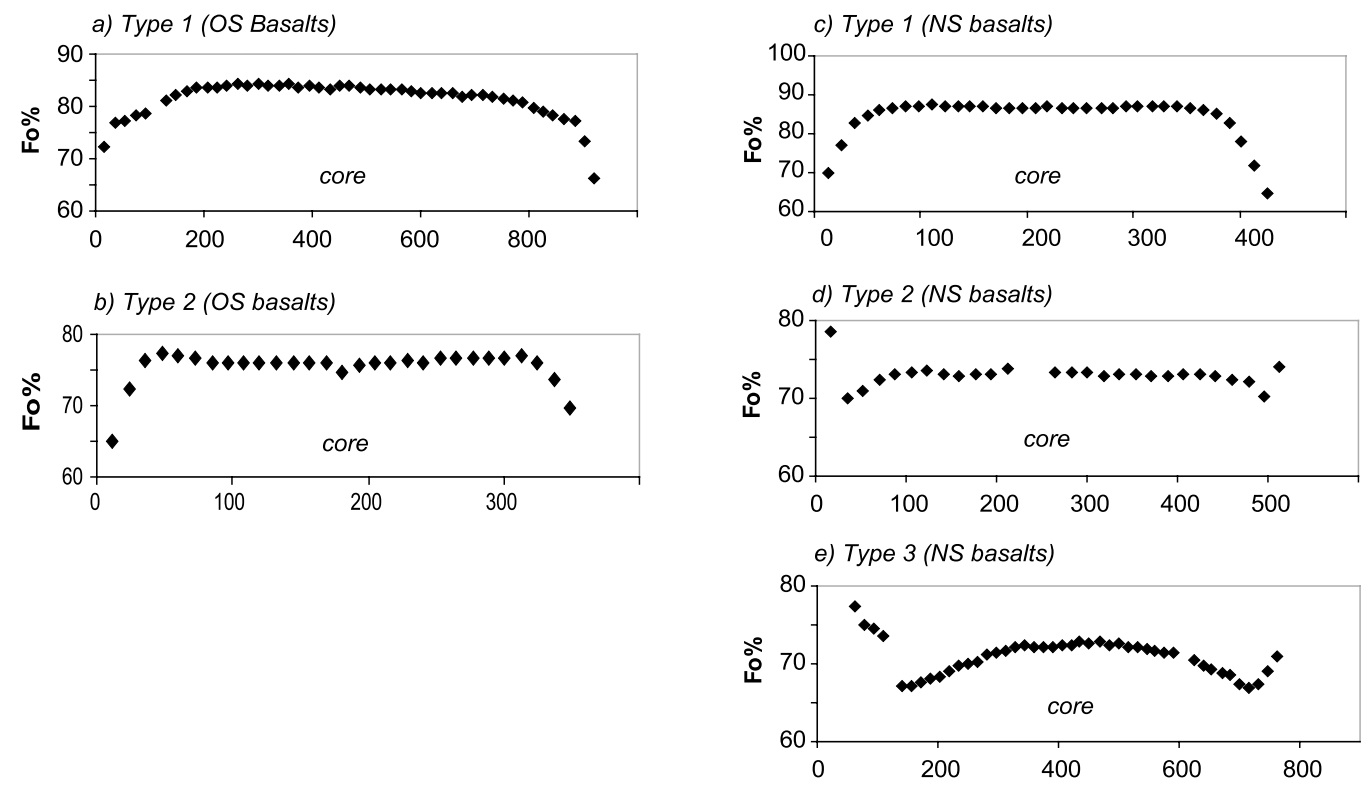

Fig. 5. Zoning patterns of the olivines. (a) Type 1 olivine in OS basalts. (b) Type 2 olivine in the OS basalts. (c) Type 1 olivine in the NS basalts. (d) Type 2 olivine in the NS basalts. (e) Type 3 olivine in the NS basalts.

and NS basalts, whereas the high-NiO population is composed solely of olivines from OS basalts. Also shown in Fig. 6 is the trend produced by fractionation of $5 \mathrm{wt} \%$ of olivine from a liquid in equilibrium with the most $\mathrm{Mg}$-rich analysed olivine $\left(\mathrm{Fo}_{92}\right)$, calculated using the equations of Roeder and Emslie (1970) for $\mathrm{MgO}$ and $\mathrm{FeO}$ and a temperature of $1300^{\circ} \mathrm{C}$. $D_{\mathrm{Ni} \mathrm{ol} / \text { liq }}$ was estimated from the $\mathrm{MgO}$ content of the liquid using the equation of Kinzler et al. (1990). The observed relationship indicates that the two populations are not related by fractional crystallisation and suggests that they instead represent two distinct fractionation trends that formed in different liquids.

\subsection{Spinel}

Chromian spinel is found as small $(10-20 \mu \mathrm{m})$ euhedral reddish-brown inclusions in Type 1 olivine phenocrysts. Opaque spinel with significant Ti-magnetite component (more than $1.5 \mathrm{wt} \%$ $\mathrm{TiO}_{2}$ ) is common in Fe-rich olivines. Sample S108 lacks Cr-spinel, probably reflecting the scar-

Table 4

Representative compositions of olivine cores

\begin{tabular}{|c|c|c|c|c|c|c|c|c|c|c|c|c|c|c|c|c|c|c|}
\hline & \multicolumn{10}{|c|}{ Old Slamet } & \multicolumn{8}{|c|}{ New Slamet } \\
\hline & $\mathrm{S} 30$ & S30 & $\mathrm{S} 30$ & S30 & $\mathrm{S} 30$ & S154 & $\mathrm{S} 154$ & S154 & S154 & S154 & S222 & S222 & S222 & S222 & $\mathrm{S} 108$ & S108 & S108 & S108 \\
\hline $\mathrm{SiO}_{2}$ & 40.86 & 40.08 & 39.31 & 39.91 & 37.16 & 40.38 & 39.32 & 39.58 & 39.16 & 36.59 & 39.87 & 39.31 & 39.27 & 35.30 & 40.27 & 39.72 & 36.05 & 36.04 \\
\hline $\mathrm{FeO}^{*}$ & 7.85 & 7.93 & 11.24 & 12.45 & 26.83 & 8.88 & 13.08 & 13.52 & 14.12 & 27.97 & 10.45 & 12.32 & 14.93 & 31.96 & 9.94 & 15.44 & 31.99 & 33.59 \\
\hline $\mathrm{MnO}$ & 0.13 & 0.12 & 0.19 & 0.15 & 0.43 & 0.10 & 0.20 & 0.24 & 0.16 & 0.52 & 0.16 & 0.20 & 0.23 & 0.60 & 0.13 & 0.24 & 0.43 & 0.45 \\
\hline $\mathrm{MgO}$ & 50.31 & 50.30 & 47.83 & 47.21 & 35.41 & 49.82 & 46.03 & 46.02 & 45.33 & 34.32 & 48.20 & 46.91 & 44.51 & 30.75 & 49.29 & 44.87 & 31.44 & 30.06 \\
\hline $\mathrm{CaO}$ & 0.10 & 0.13 & 0.20 & 0.12 & 0.19 & 0.13 & 0.15 & 0.22 & 0.16 & 0.22 & 0.16 & 0.17 & 0.15 & 0.25 & 0.18 & 0.16 & 0.26 & 0.24 \\
\hline $\mathrm{NiO}$ & 0.42 & 0.42 & 0.22 & 0.37 & 0.08 & 0.40 & 0.31 & 0.20 & 0.29 & 0.07 & 0.28 & 0.22 & 0.14 & 0.04 & 0.29 & 0.15 & 0.06 & 0.04 \\
\hline Total & 99.68 & 98.97 & 99.00 & 100.19 & 100.11 & 99.71 & 99.09 & 99.78 & 99.22 & 99.69 & 99.13 & 399.13 & 99.23 & 98.91 & 100.10 & 100.59 & 100.23 & 100.43 \\
\hline $\begin{array}{l}\mathrm{mol} \% \\
\mathrm{Fo}\end{array}$ & 92.0 & 91.9 & 88.4 & 87.1 & 70.2 & 90.9 & 86.2 & 85.9 & 85.1 & 68.6 & 89.2 & 87.2 & 84.2 & 63.2 & 89.8 & 83.8 & 63.7 & 61.5 \\
\hline
\end{tabular}


city of $\mathrm{Mg}$-rich $(\mathrm{Fo} \%>75)$ olivine in this sample.

The chromian spinels have variable and relatively high $\mathrm{Cr} \#(50-80 ; \mathrm{Cr} \#=100 \times \mathrm{Cr} /(\mathrm{Cr}+\mathrm{Al}))$ (Fig. 7a; Table 5). They lie outside the olivinespinel mantle array defined by Arai (1992) and have a compositional range typical of arc magmas (Fig. 7b). Almost the entire observed $\mathrm{Cr} \#$ range is present at any given $\mathrm{Fo} \%$ of host olivine. $\mathrm{Al}_{2} \mathrm{O}_{3}$ and $\mathrm{TiO}_{2}$ contents of spinels also show large variations at a given $\mathrm{Fo} \%$ of the host olivine (9-20 $\mathrm{wt} \%$ and $0.2-1.3 \mathrm{wt}^{\%} \%$ respectively) (Fig. 7c). Chromian spinel inclusions within the OS high$\mathrm{NiO}$ olivine sub-population have lower $\mathrm{Al}_{2} \mathrm{O}_{3}$ (higher $\mathrm{Cr} \#$ ) and $\mathrm{TiO}_{2}$ content and higher $\mathrm{Fe}^{2+} /$ $\mathrm{Fe}^{3+}$ ratio than those within the OS and NS low$\mathrm{NiO}$ olivine sub-population (Fig. 7a-d). Experimental and empirical studies have demonstrated that $\mathrm{Al}$ and $\mathrm{Ti}$ contents of $\mathrm{Cr}-$ spinel are essentially controlled by the melt composition (Roeder and Reynolds, 1991; Arai, 1992; Kamenetsky et al., 2001), which reinforces the view that the two populations of olivine and their $\mathrm{Cr}-$-spinel inclusions crystallised in different liquids.

\subsection{Plagioclase}

Plagioclase phenocrysts show contrasted features in the OS and NS basalts, despite similar whole-rock compositions. The differences are summarised, along with those of pyroxene, in Table 6. Plagioclase in the OS basalts ranges in composition from $\mathrm{An}_{89}$ to $\mathrm{An}_{53}$ (Fig. 8; Table 7). Multiple concentric sieve-textured zones charged with glass inclusions are ubiquitous but are often accompanied by only small variations in An $(<5 \%)$ content (Fig. 9a). Most crystals display a broad interval with small repetitive variations in composition $\left(\mathrm{An}_{85-73}\right)$ enclosed by a narrow normally zoned rim $\left(\mathrm{An}_{85-60}\right)$ (Fig. 9a, Table 6). Occasional crystals showing normal and reverse zoning are also observed (Fig. 9b; Table 6). Groundmass plagioclases range in composition from $\mathrm{An}_{70}$ to $\mathrm{An}_{54}$.

Plagioclase in NS basalts has a more restricted composition range, from $\mathrm{An}_{82}$ to $\mathrm{An}_{60}$ for $\mathrm{S} 108$ and from $\mathrm{An}_{87}$ to $\mathrm{An}_{72}$ for S222 (Fig. 8; Table 7). Most crystals have a sieve-textured core $\left(\mathrm{An}_{80-75}\right)$

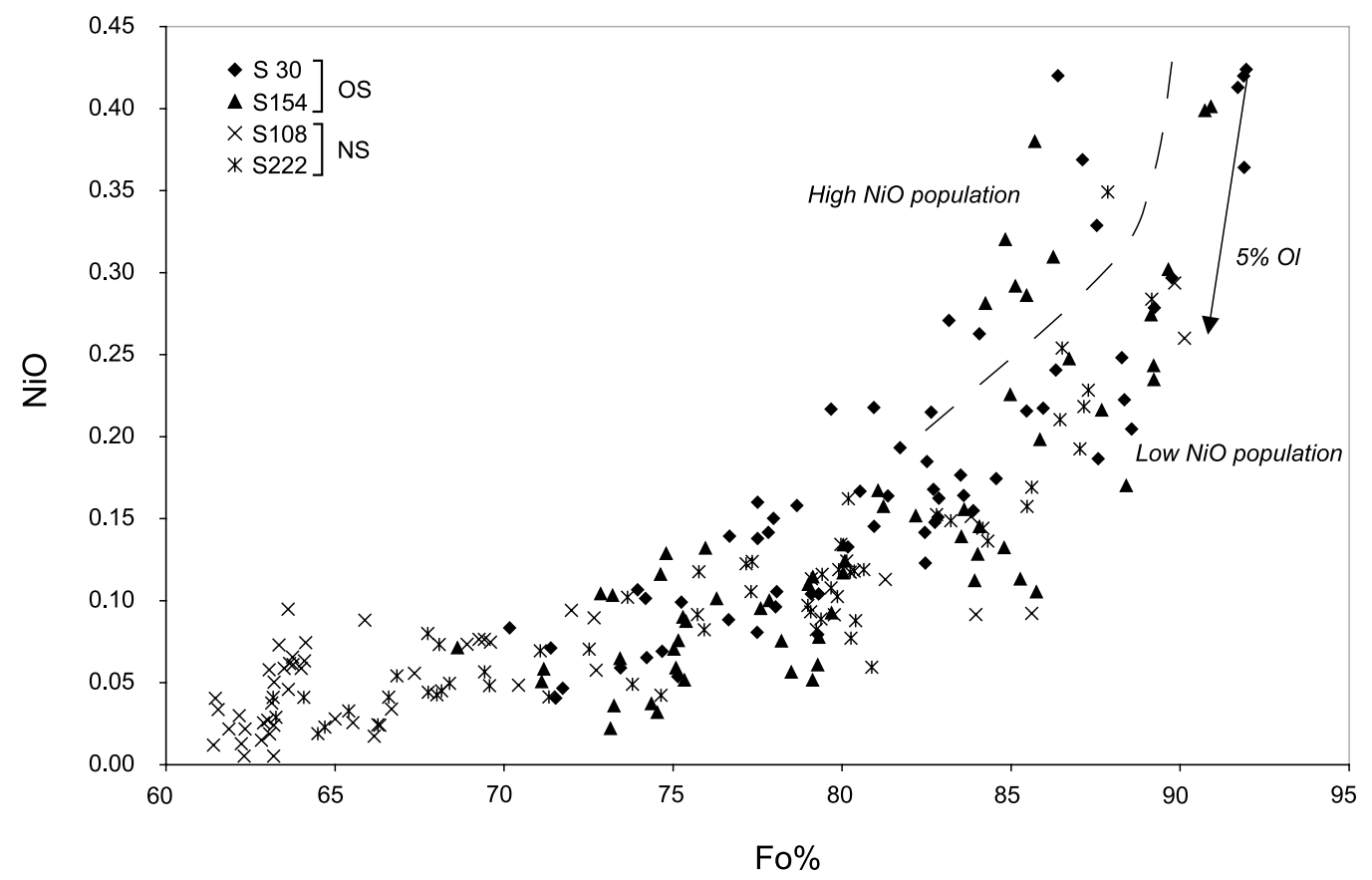

Fig. 6. Diagram showing the $\mathrm{NiO}$ content (wt $\%$ ) vs $\mathrm{Fo} \%$ for olivine phenocrysts in each lava. Arrows mark the effect of $5 \%$ of fractional crystallisation of olivine (see text for calculation method). 
overgrown by a clear normally zoned rim $\left(\mathrm{An}_{83-70}\right)$. Rare crystals show a normally zoned core $\left(\mathrm{An}_{87-67}\right)$ surrounded by a sieved zone and a normally zoned rim $\left(\mathrm{An}_{80-70}\right)$ (Fig. 9c, Table 6). The sieved zones correlate with moderate to large variations in An content (10-15\%). Groundmass plagioclases range from $\mathrm{An}_{73}$ to $\mathrm{An}_{68}$.

Equilibrium between plagioclases and wholerock compositions may be tested using experimental equilibrium distribution coefficients ${ }^{\mathrm{Ca} / \mathrm{Na}} K_{\mathrm{D} \min / \mathrm{liq}}\left(=X_{\mathrm{Ca}}^{\mathrm{plag}} \times X_{\mathrm{Na}}^{\mathrm{liq}} / X_{\mathrm{Na}}^{\mathrm{plag}} \times X_{\mathrm{Ca}}^{\mathrm{liq}}\right)$. However, these values depend upon all of melt composition, temperature, pressure and $\mathrm{H}_{2} \mathrm{O}$ content (e.g. Sisson and Grove, 1993; Panjasawatwong et al., 1995), parameters which are essentially unknown and probably variable for the Slamet basaltic magmas. Nevertheless, for basaltic melts crystallised under $\mathrm{H}_{2} \mathrm{O}$-undersaturated to $\mathrm{H}_{2} \mathrm{O}$ -
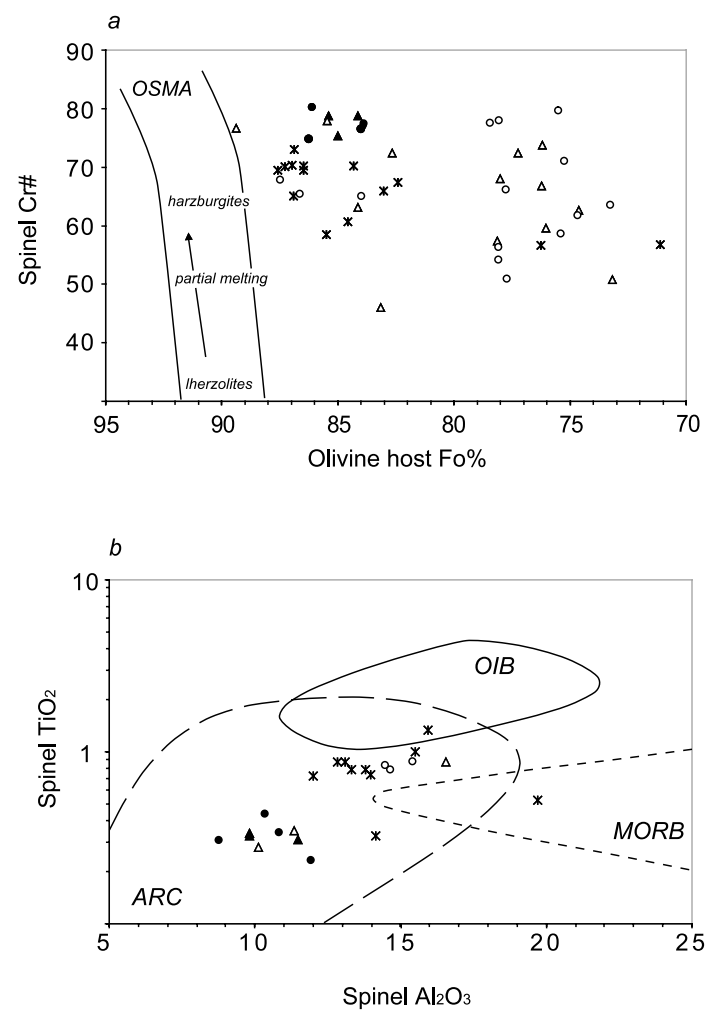

saturated conditions at varying melt $\mathrm{H}_{2} \mathrm{O}$ contents and pressures, $K_{\mathrm{D}}^{\mathrm{Ca}-\mathrm{Na}}$ values are largely between 2 and 5.5. The cores of the plagioclase in OS basalts are essentially in equilibrium with whole-rock compositions, whereas the cores of the plagioclase in the NS basalts are generally anomalously sodic (Fig. 8). In the latter basalts only the clear zones enclosing the sieved-textured cores are in equilibrium with whole-rock compositions.

Repeated, fine-scale and small compositional changes $(<5 \mathrm{An} \%)$ that commonly occur in volcanic plagioclases are thought to reflect near-equilibrium incremental diffusion-controlled growth (Pearce and Kolisnik, 1990; Singer et al., 1995). Sieved textures accompanied by significant compositional variations are often regarded as indicative of magma mixing with subsequent plagioclase
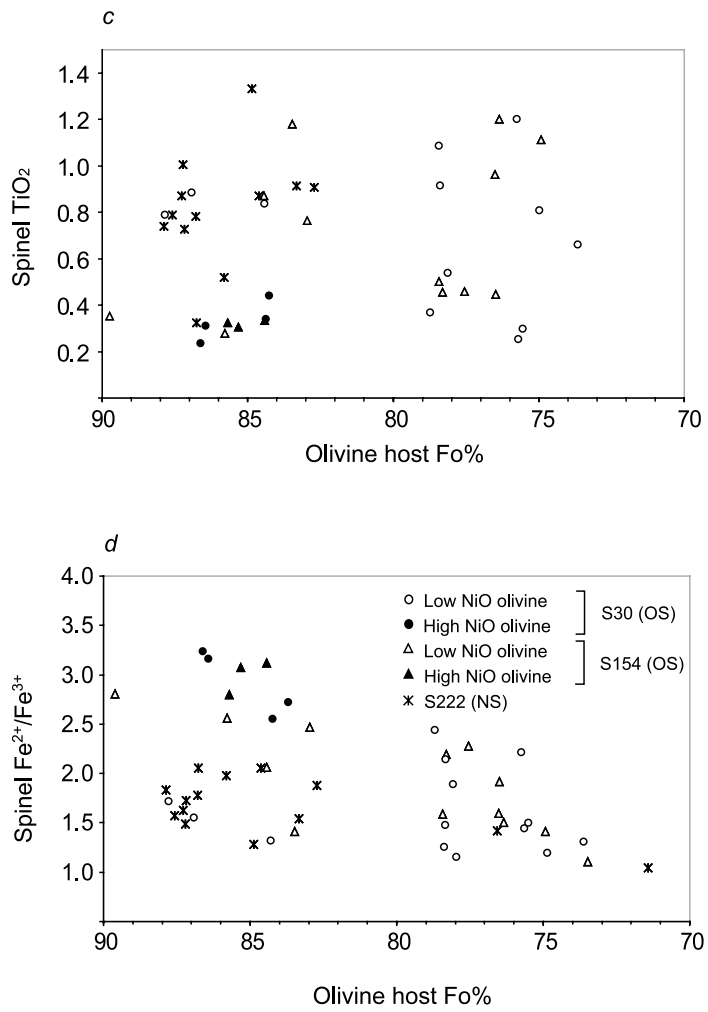

Fig. 7. Compositional relationship between $\mathrm{Cr}-$ spinel inclusions and their host olivines. (a) Plot of $\mathrm{Cr} \#$ spinel vs $\mathrm{Fo} \%$ of host olivine showing the olivine-spinel mantle array (OSMA) from Arai (1987). The arrow indicates the effect of partial melting on re-

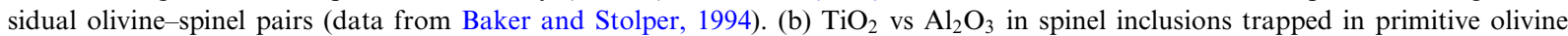
$\mathrm{Fo}>84$. Compositional fields from Kamenetsky et al. (2001). (c) $\mathrm{TiO}_{2}$ spinel inclusion vs $\mathrm{Fo}_{\%}$ host olivine. (d) Spinel inclusion $\mathrm{Fe}^{2+} / \mathrm{Fe}^{3+}$ ratio vs $\mathrm{Fo} \%$ host olivine. 
Table 5

Representative compositions of spinel inclusions in olivine

\begin{tabular}{|c|c|c|c|c|c|c|c|c|c|c|c|}
\hline & \multicolumn{8}{|c|}{ Old Slamet } & \multicolumn{3}{|c|}{ New Slamet } \\
\hline & $\mathrm{S} 30$ & S30 & S30 & $\mathrm{S} 30$ & S154 & S154 & S154 & S154 & S222 & S222 & S222 \\
\hline $\mathrm{SiO}_{2}$ & 1.37 & 0.10 & 0.16 & 0.31 & 0.20 & 0.21 & 0.22 & 0.28 & 0.18 & 0.12 & 0.10 \\
\hline $\mathrm{TiO}_{2}$ & 0.31 & 0.83 & 0.34 & 0.78 & 0.76 & 0.33 & 0.87 & 0.28 & 0.91 & 0.74 & 2.00 \\
\hline $\mathrm{Al}_{2} \mathrm{O}_{3}$ & 8.77 & 14.52 & 10.81 & 14.62 & 11.64 & 9.81 & 16.54 & 10.11 & 14.34 & 13.95 & 16.38 \\
\hline $\mathrm{Fe}_{2} \mathrm{O}_{3}$ & 7.90 & 15.91 & 7.30 & 10.65 & 11.24 & 6.99 & 10.38 & 8.04 & 13.83 & 10.01 & 18.71 \\
\hline $\mathrm{FeO}$ & 22.39 & 18.91 & 18.34 & 16.63 & 24.99 & 19.62 & 19.27 & 18.50 & 19.20 & 16.48 & 23.95 \\
\hline $\mathrm{MnO}$ & 0.28 & 0.21 & 0.16 & 0.14 & 0.32 & 0.17 & 0.11 & 0.15 & 0.18 & 0.09 & 0.33 \\
\hline $\mathrm{MgO}$ & 7.26 & 10.53 & 10.03 & 11.99 & 6.06 & 9.26 & 10.36 & 9.94 & 10.17 & 12.07 & 8.04 \\
\hline $\mathrm{Cr}_{2} \mathrm{O}_{3}$ & 53.60 & 40.22 & 52.63 & 45.79 & 45.42 & 54.25 & 42.21 & 53.17 & 41.34 & 47.46 & 31.88 \\
\hline Total & 101.88 & 101.23 & 99.77 & 100.92 & 100.63 & 100.63 & 99.97 & 100.46 & 100.15 & 100.92 & 101.40 \\
\hline Mg\# & 36.6 & 49.8 & 49.4 & 56.2 & 30.2 & 45.7 & 48.9 & 48.9 & 48.6 & 56.6 & 37.4 \\
\hline $\mathrm{Cr} \#$ & 80.4 & 65.0 & 76.6 & 67.7 & 72.4 & 78.8 & 63.1 & 77.9 & 65.9 & 69.5 & 56.6 \\
\hline $\mathrm{Fe}^{2+} / \mathrm{Fe}^{3+}$ & 3.1 & 1.3 & 2.8 & 1.7 & 2.5 & 3.1 & 2.1 & 2.6 & 1.5 & 1.8 & 1.4 \\
\hline Host $\mathrm{Fo}^{0} \%$ & 86.4 & 84.3 & 84.3 & 87.8 & 83.0 & 84.4 & 84.4 & 85.8 & 83.3 & 87.9 & 76.6 \\
\hline Host $\mathrm{NiO}$ & 0.42 & 0.25 & 0.31 & 0.26 & 0.21 & 0.37 & 0.20 & 0.22 & 0.19 & 0.24 & 0.07 \\
\hline
\end{tabular}

resorption but can also be produced by significant decompression and change in volatile content (Tsuchiyama, 1985; Pearce and Kolisnik, 1990; Singer et al., 1995). The repetitive occurrence of concentric sieve-textured zones which are accom- panied by small variations in An content $(<5 \%)$ in the OS plagioclase suggests that they could result mainly from variations in pressure or more likely variations in volatile content and/or temperature. In the case of NS plagioclase, the

Table 6

Summary of the different zoning patterns for the plagioclases and pyroxenes

Crystal zon-Old Slamet basalts New Slamet basalts

ing patterns

\begin{tabular}{|c|c|c|c|c|}
\hline & & \\
\hline & Plagioclase & Pyroxene & Plagioclase & Pyroxene \\
\hline Dominant & $\begin{array}{l}\text { multiple sieve-textured zones, } \\
\text { broad core with small oscillatory } \\
\text { variation in composition } \mathrm{An}_{85-73} \text {, } \\
\text { normally zoned rim } \mathrm{An}_{85-65} ; \text { most } \\
\text { sieve-textured zones associated with } \\
\text { small variations in composition }\end{array}$ & $\begin{array}{l}\text { weak oscillatory } \\
\text { zoning } \mathrm{Mg} \# \text { 80-77 }\end{array}$ & $\begin{array}{l}\text { sieve-textured core } \mathrm{An}_{80-75} \\
\text { enclosed by a normally zoned } \\
\text { rim } \mathrm{An}_{83-70} \text {; sieve-textured zones } \\
\text { associated with moderate to large } \\
\text { variation in composition }\end{array}$ & $\begin{array}{l}\text { core with weak } \\
\text { oscillatory zoning } \\
\text { Mg\#74-68 enclosed by } \\
\text { a sieve-textured zone } \\
\text { and a narrow rim } \\
\mathrm{Mg} \# 85-78 \\
\text { sieve-textured core } \\
\text { enclosed by narrow rim } \\
\mathrm{Mg} \# 85-78\end{array}$ \\
\hline
\end{tabular}

Occasional multiple sieve-textured zones, normally zoned core $\mathrm{An}_{89-65}$

reversely zoned core Mg\# 70-86 enclosed by a reversely zoned zone enclosed by a $\mathrm{An}_{70-83}$ and a normally zoned rim normally zoned $\mathrm{An}_{83-65}$; sieve-textured zones associated with small to moderate variation in composition rim $\mathrm{Mg} \#$ 85-76 normally zoned core $\mathrm{An}_{87-67}$ enclosed by a sieve-textured zone and a normally zoned rim $\mathrm{An}_{80-70}$; sieve-textured zones associated with moderate to large variation in composition weak oscillatory zoning Mg\# 85-78

normally zoned Mg\# 85-78

orthopyroxene core $\mathrm{Mg} \#$ 68-67 enclosed by a clinopyroxene rim $\mathrm{Mg} \# 85-75$ 


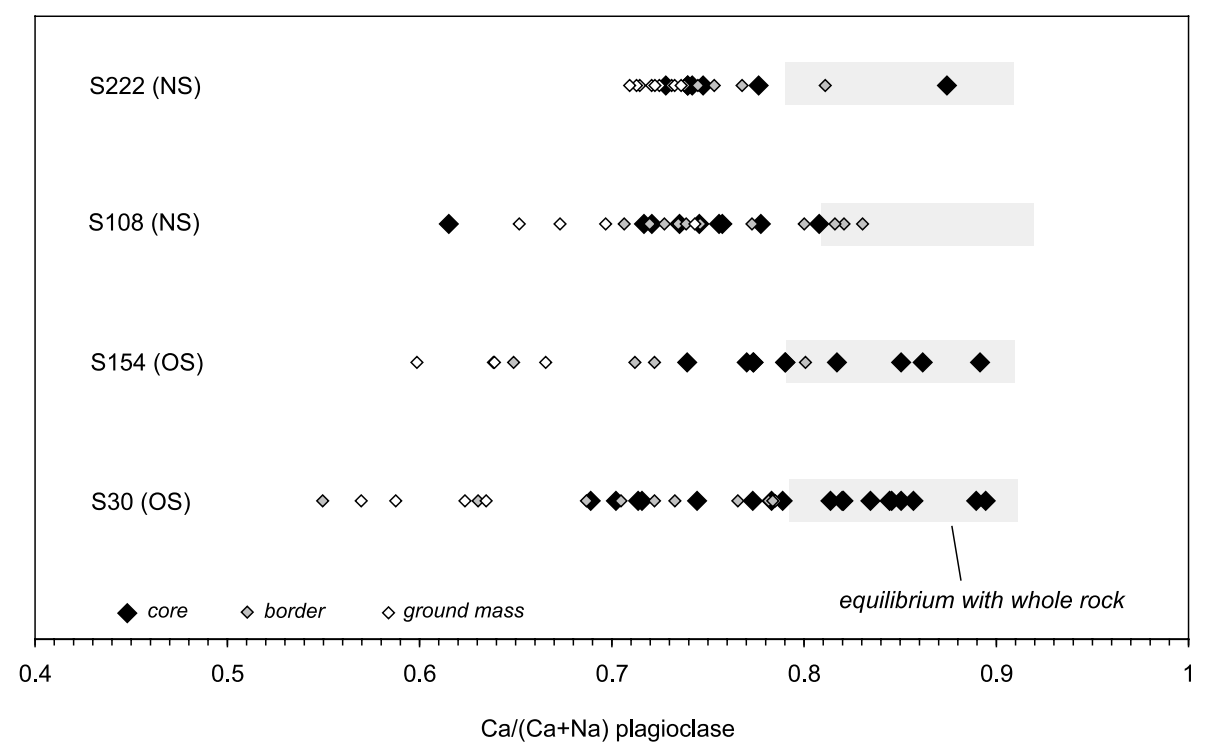

Fig. 8. Ranges of plagioclase composition in each sample. Boxes represent the range of plagioclase compositions in equilibrium with whole-rock compositions calculated using ${ }^{\mathrm{Ca} / \mathrm{Na}} K_{\mathrm{D} \text { min/liq }}$ values of 2-5.5 (Sisson and Grove, 1993; Panjasawatwong et al., 1995).

large increase in $\mathrm{An} \%$ associated with sieve-textured zones seems to indicate that incorporation of these crystals into a more mafic melt was the principal cause of resorption, which is consistent with the anomalously sodic composition of the cores.

\subsection{Pyroxenes}

Representative pyroxene analyses are presented in Table 8. Clinopyroxenes are augites with $47-$ $34 \%$ Wo and $54-38 \%$ En. The jacketed orthopyroxene crystals found in NS basalts are hypersthenes with 4\% Wo and 66-63\% En. Clinopyroxene phenocrysts in OS basalts have mg\# ranges of $95-82$ for S30 and 92-81 for S154 (Fig. 10). Groundmass pyroxenes have mg\# 8276. Clinopyroxene phenocrysts in NS basalts have a larger range of mg\# (94-70) (Fig. 10). Groundmass pyroxenes have mg\# 90-82.

Table 7

Representative compositions of plagioclase

\begin{tabular}{|c|c|c|c|c|c|c|c|c|}
\hline & \multicolumn{4}{|c|}{ Old Slamet } & \multicolumn{4}{|c|}{ New Slamet } \\
\hline & $\begin{array}{l}\text { S30 } \\
\text { core }\end{array}$ & $\begin{array}{l}\mathrm{S} 30 \\
\text { border }\end{array}$ & $\begin{array}{l}\text { S30 } \\
\text { gm }\end{array}$ & $\begin{array}{l}\text { S154 } \\
\text { core }\end{array}$ & $\begin{array}{l}\text { S108 } \\
\text { core }\end{array}$ & $\begin{array}{l}\mathrm{S} 108 \\
\text { border }\end{array}$ & $\begin{array}{l}\text { S222 } \\
\text { core }\end{array}$ & $\begin{array}{l}\text { S222 } \\
\mathrm{gm}\end{array}$ \\
\hline $\mathrm{SiO}_{2}$ & 45.17 & 48.46 & 52.47 & 46.16 & 49.34 & 47.41 & 49.34 & 49.49 \\
\hline $\mathrm{Al}_{2} \mathrm{O}_{3}$ & 34.03 & 31.22 & 28.29 & 32.96 & 31.23 & 32.52 & 31.00 & 30.51 \\
\hline $\mathrm{Fe}_{2} \mathrm{O}_{3}$ & 0.66 & 0.58 & 1.18 & 0.59 & 0.59 & 0.58 & 0.69 & 0.89 \\
\hline $\mathrm{CaO}$ & 18.71 & 16.21 & 12.77 & 17.99 & 15.66 & 17.00 & 15.61 & 15.22 \\
\hline $\mathrm{NaO}$ & 1.22 & 2.45 & 4.26 & 1.60 & 2.77 & 2.05 & 3.04 & 3.23 \\
\hline $\mathrm{K}_{2} \mathrm{O}$ & 0.05 & 0.11 & 0.29 & 0.06 & 0.13 & 0.10 & 0.10 & 0.13 \\
\hline Total & 99.8 & 99.0 & 99.3 & 99.4 & 99.7 & 99.7 & 99.8 & 99.5 \\
\hline An & 89.2 & 78.0 & 61.3 & 85.9 & 75.2 & 81.6 & 73.5 & 71.7 \\
\hline $\mathrm{Ab}$ & 10.5 & 21.4 & 37.0 & 13.8 & 24.1 & 17.8 & 25.9 & 27.6 \\
\hline Or & 0.3 & 0.6 & 1.6 & 0.3 & 0.7 & 0.6 & 0.5 & 0.7 \\
\hline
\end{tabular}



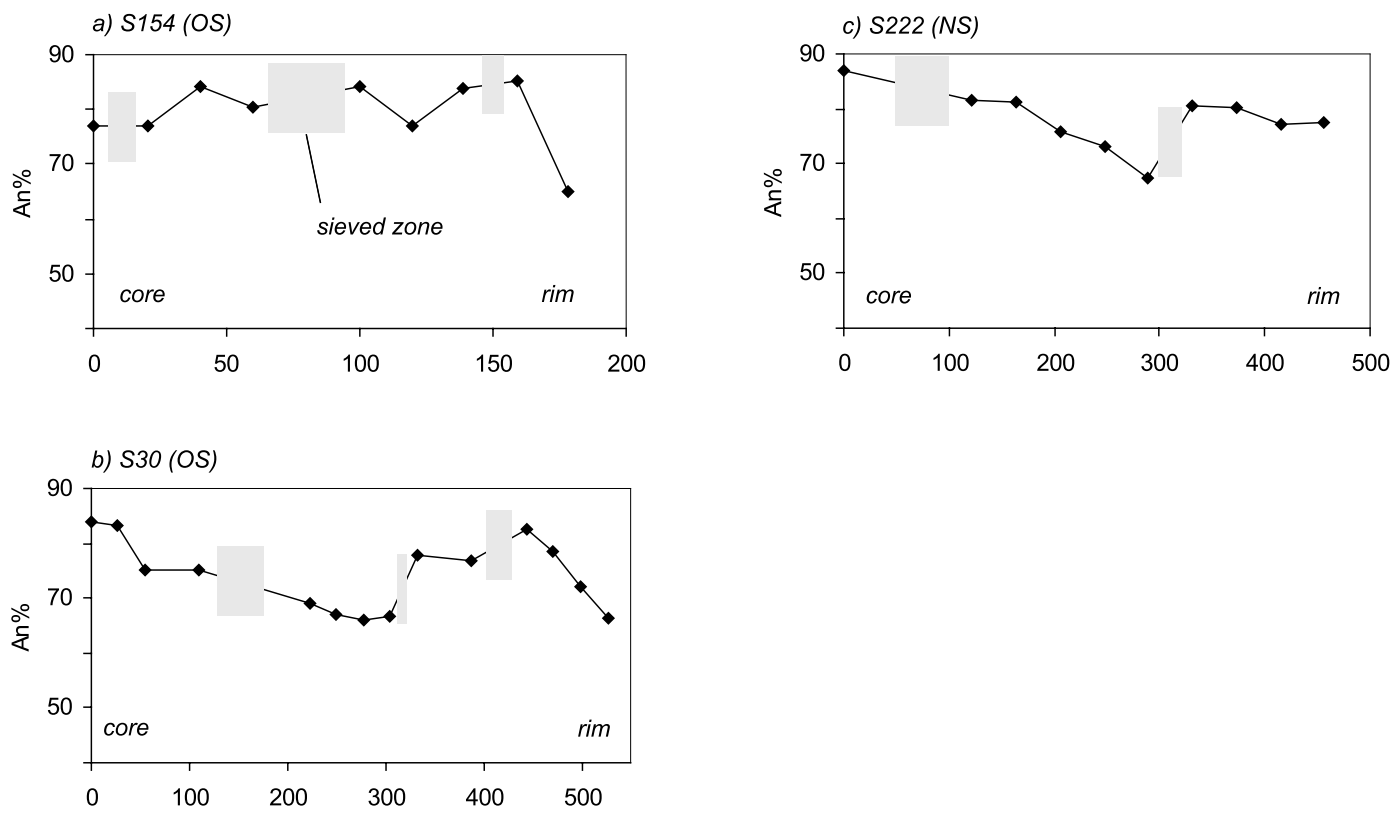

Fig. 9. Typical zoning patterns of some selected plagioclase phenocrysts.

Calculated mg\# for pyroxenes in equilibrium with whole-rock compositions using $\mathrm{Fe} / \mathrm{Mg} K_{\mathrm{D} \text { min/whole-rock }}$ 0.23-0.3 (Sisson and Grove, 1993) are shown in Fig. 10. In the OS basalts, most clinopyroxenes are in or near equilibrium with whole-rock composition. In the NS basalts, the clinopyroxene rims are more magnesian than sieve-textured cores and also cores enclosed by a sieve-textured zone. These cores (comprising the jacketed orthopyroxene) are clearly not in equilibrium with a basaltic melt.

Different zoning patterns are observed and are summarised in Table 6. Clinopyroxene in OS basalts typically shows weak oscillatory zoning (mg\# 90-85) (Fig. 11a). Phenocrysts normally zoned (mg\# 93-85) or with reversely zoned cores (mg\# 80-93) are occasionally observed (Fig. 11b). In NS basalts, clinopyroxene is dominantly reversely zoned (mg\# 75-70 to 94-85) (Fig. 11c) and reverse zoning is always associated with a sieve-textured zone. Rare phenocrysts with weak oscillatory zoning (mg\# 90-85) are also present. The orthopyroxene cores (mg\# 72-70) are mantled by a rim of clinopyroxene with $\mathrm{mg \#}$ 92-87.

\section{Discussion}

\subsection{Primary magmas}

The presence of two distinct populations of olivine and $\mathrm{Cr}$-spinel indicate that two contrasted parental magmas were involved in the genesis of the OS basalts. Several factors might explain the existence of two parental melts, such as different fractionation paths from a common primary magma, a heterogeneous mantle source or variable degrees of source melting. The high $\mathrm{NiO}$ content $(0.42 \mathrm{wt} \%)$ of the more magnesian olivines in both populations (Fig. 6) implies that the two parental liquids were near-primary. Therefore, it is unlikely that they originated from a common primary liquid by contrasted fractional crystallisation paths. Experiments by Baker and Stolper (1994) have demonstrated that $\mathrm{Cr} \#$ (or $\mathrm{Al}_{2} \mathrm{O}_{3}$ ) of restite spinel increases with increasing degree of melting (1.5 $\mathrm{Cr} \#$ per $1 \%$ increase in degree of melting). Assuming that the liquidus spinel in primary magma is close in composition to that of the residual spinel in the magma source, variations in the degree of partial melting could account for the ob- 
Table 8

Representative compositions of pyroxene

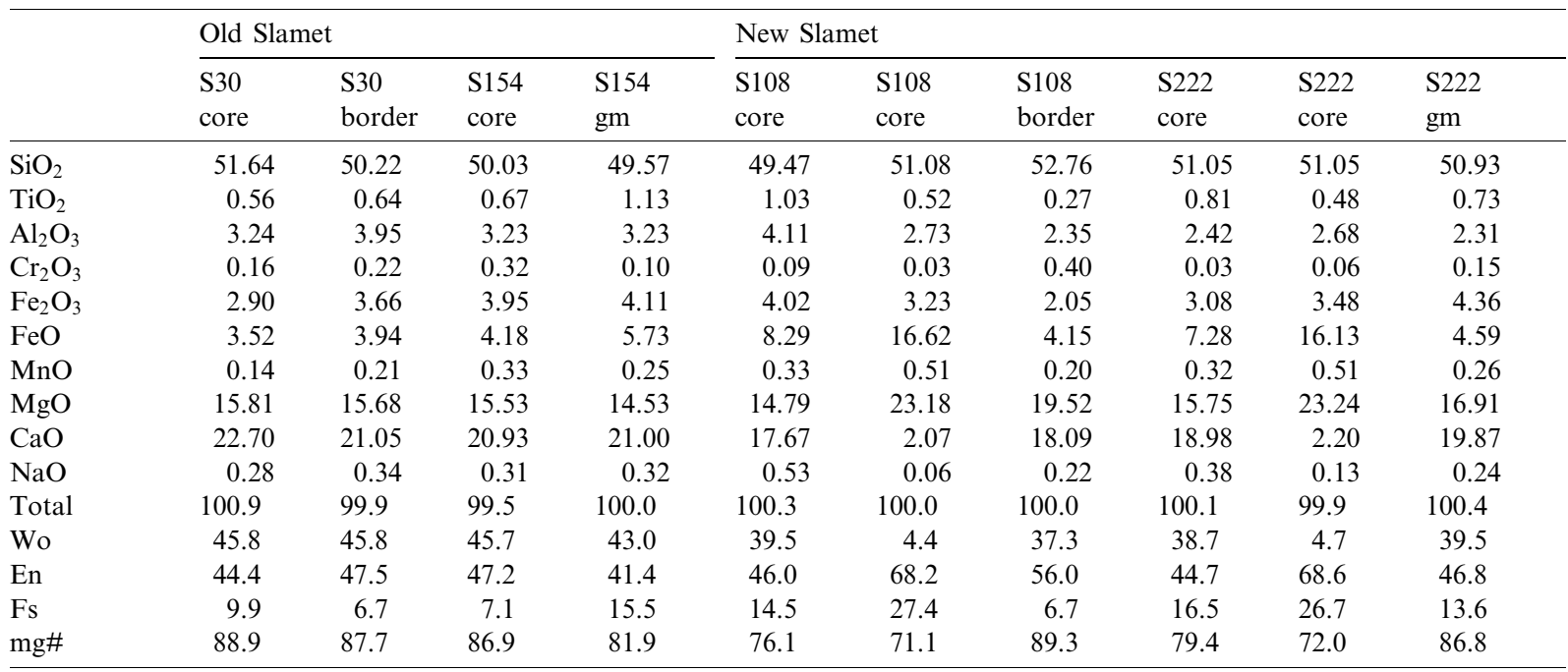

served variation in $\mathrm{Cr}$-spinel $\mathrm{Cr} \#$ (variation of $13 \%$ in degree of melting would be required). However, olivines that crystallise in a liquid produced by a higher degree of partial melting are expected to be more Fo-rich as the liquid has higher Mg\# (Jaques and Green, 1980; Hirose and Kushiro, 1993; Baker and Stolper, 1994). This is contrary to our observations, since the olivines which contain high-Cr\# spinels belong to the high-NiO population that is characterised by lower maximum $\mathrm{Fo}_{\%}$ (Fig. 6). Consequently, variations in the degree of partial melting cannot alone explain the covariation in spinel and olivine compositions.

Source fertility is another factor that controls the compositions of spinel and olivine. Fertile spinel lherzolites and pyroxenites contain lowerCr\# spinel and lower-Fo olivine, and less fertile harzburgites contain a higher-Cr\# spinel and higher-Fo olivine (Dick and Fisher, 1984) (Fig. 7a). Assuming that the initial compositions of the spinels and olivines crystallising from the magma were not significantly different from their equivalents in the source, the same relationship would be expected if the two liquids were produced from two different sources with variable fertility under the same conditions (pressure and temperature) of mantle melting. Again this is not in accord with our data because, as previously noted, spinels with high Cr\# occur within the olivine population with lower Fo. From the above discussion it is clear that no 'simple' model can account for the relationship between the chemistry of the host olivines and spinel inclusions.

Intensive parameters such as pressure, $f \mathrm{O}_{2}$ and water content of the melt influence the chemistry of the crystallising phases. Pressure affects the Al content and $\mathrm{Al} / \mathrm{Cr}$ ratio of chromian spinel. Spinel crystallised at higher pressure is expected to have higher $\mathrm{Al}$ content and $\mathrm{Al} / \mathrm{Cr}$ (lower $\mathrm{Cr} \#$ ) values than spinel crystallised at lower pressure (Dick and Bullen, 1984; Ballhaus et al., 1991). Increase in $f \mathrm{O}_{2}$ leads to decrease in $\mathrm{Cr}_{2} \mathrm{O}_{3}, \mathrm{Al}_{2} \mathrm{O}_{3}, \mathrm{Fe}^{2+} /$ $\mathrm{Fe}^{3+}$ and $\mathrm{Cr} \#$ (Roeder and Reynolds, 1991). However variations in spinel composition due to changes in intensive parameters are small (Clynne and Borg, 1997) and cannot account for the apparently incoherent covariations between compositions of spinel inclusions and their olivine hosts observed in the Slamet basalts.

The exchange coefficient ${ }^{\mathrm{Fe} / \mathrm{Mg}} K_{\mathrm{D} \text { min/liq }}$ for olivine is considered to be independent of melt composition and temperature (Roeder and Emslie, 1970; Ulmer, 1989). A positive correlation between $\mathrm{Fe} / \mathrm{Mg} K_{\mathrm{D} \text { min/liq }}$ and pressure is suggested by experiments carried out by Ulmer (1989), but the resulting variations in liquidus olivine composition are too small $(\sim 1 \mathrm{Fo} \%$ per 15 kbar $)$ to 


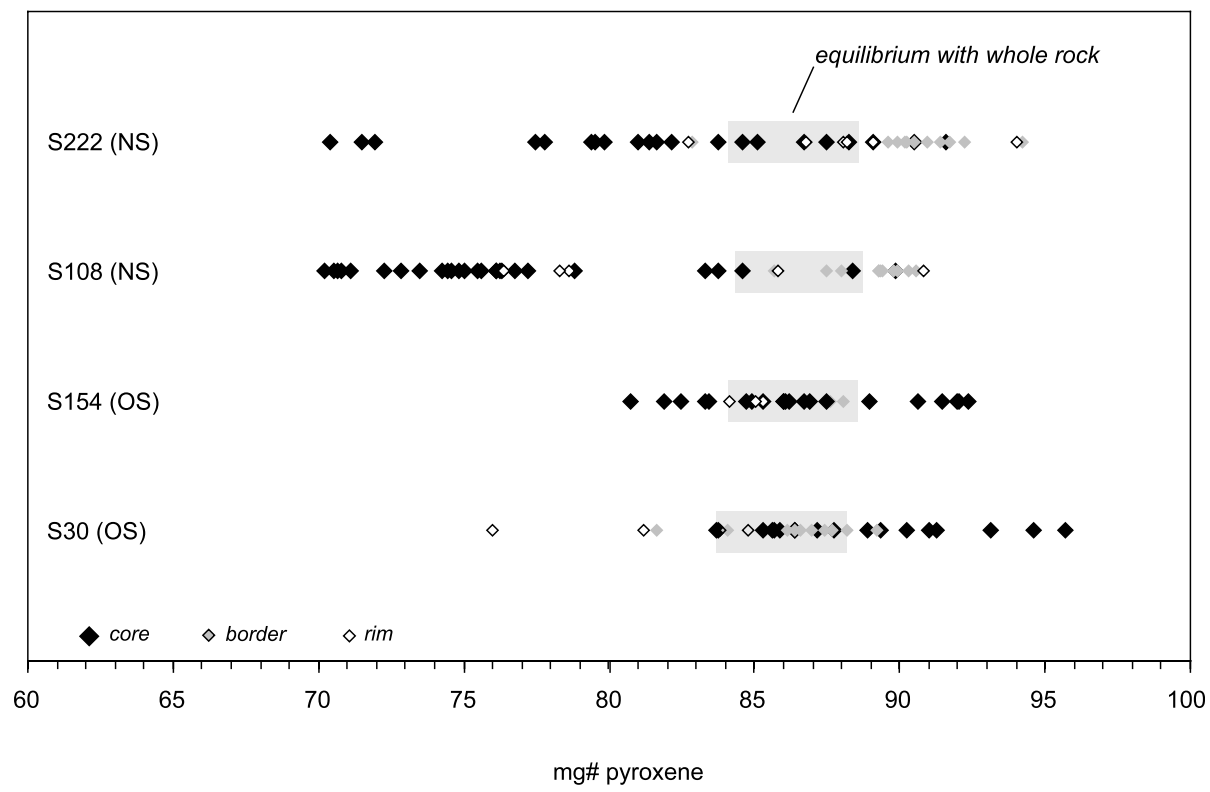

Fig. 10. Ranges of pyroxene composition in each sample. Boxes represent the ranges of pyroxene compositions in equilibrium with whole-rock compositions calculated using ${ }^{\mathrm{Fe} / \mathrm{Mg}} K_{\mathrm{D} \text { min/liq }}$ values of $0.23-0.30$ (Sisson and Grove, 1993).

explain the existence of the two observed olivine populations. Melting experiments on mantle lherzolite under anhydrous and hydrous conditions demonstrate that $\mathrm{Fe} / \mathrm{Mg} K_{\mathrm{D} \text { min/liq }}$ is independent of water content of the melt in the range $0-3$ $\mathrm{wt} \% \mathrm{H}_{2} \mathrm{O}$ (Sisson and Grove, 1993; Falloon and Danyushevsky, 2000), but that a liquid produced
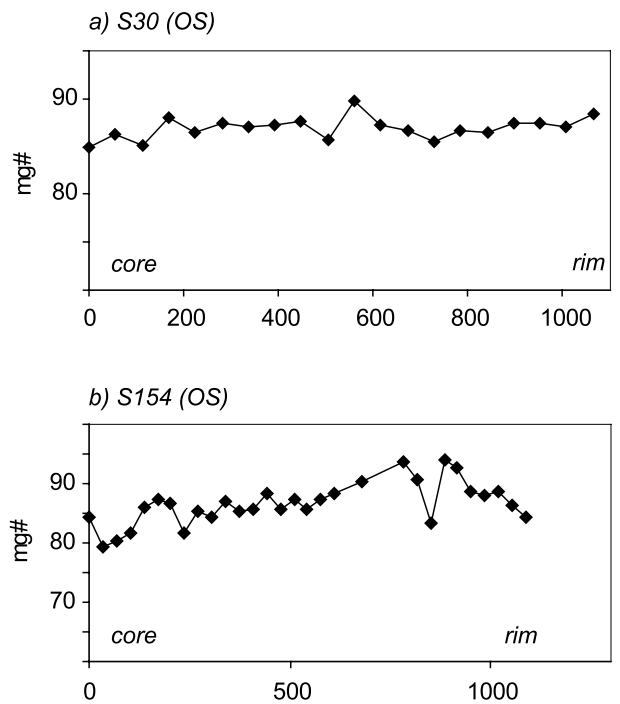

under hydrous conditions is enriched in $\mathrm{MgO}$ and depleted in $\mathrm{FeO}$ compared to its dry equivalent. As a result, olivine crystallising in a liquid produced by melting of a $\mathrm{H}_{2} \mathrm{O}$-rich mantle source is expected to have higher $\mathrm{Fo}_{0} \%$ than olivine crystallising in a liquid produced by a similar degree of melting from a similar but dry source. Conse-

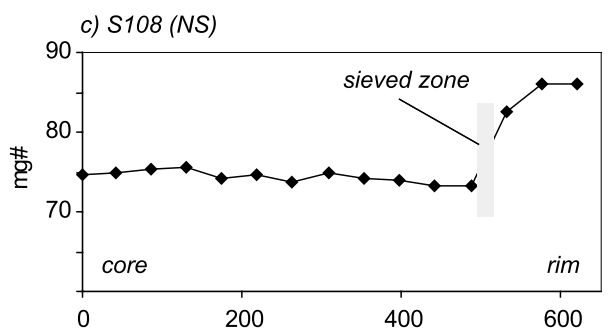

Fig. 11. Typical zoning patterns of some selected clinopyroxene phenocrysts. 
quently variation in source $\mathrm{H}_{2} \mathrm{O}$ content is regarded as the most likely cause of the apparent unsystematic variations in compositions of $\mathrm{Cr}-$ spinel inclusions and their olivine hosts, by shifting the composition of the low-NiO olivine population towards higher $\mathrm{Fo} \%$ without significantly affecting the $\mathrm{Cr}$-spinel $\mathrm{Cr} \#$. Dissociation of dissolved magmatic $\mathrm{H}_{2} \mathrm{O}$ is believed to increase $f_{2}$ of the magma (Osborn, 1959; Blundy et al., 1991). Therefore, the hydrated character of the melt associated with the low-NiO olivine population is further supported by the more oxidised Cr-spinel compositions (Fig. 7d), indicating elevated oxygen fugacity in this magma (Ballhaus et al., 1991).

Additional variations in the fertility of the source or in the degree of partial melting are required to explain the variations in $\mathrm{Al}_{2} \mathrm{O}_{3}$ and $\mathrm{TiO}_{2}$ content of the $\mathrm{Cr}-$ spinel. According to this model, the high-NiO olivine population (and high-Cr\#, low- $\mathrm{TiO}_{2}$ spinel) would have crystallised in a magma produced either from a less fertile and less hydrous source than the melt represented by the low-NiO olivines (and low-Cr\#, high $\mathrm{TiO}_{2}$ spinel) or by a higher degree of melting from a similar but dry source. The latter hypothesis is however less probable as an hydrous source would be expected to undergo a higher degree of melting than its dryer equivalent since increase in $\mathrm{H}_{2} \mathrm{O}$ content lowers the solidus temperature (Falloon and Danyushevsky, 2000).

The OS basalts are characterised by lower HFSE contents but similar LILE contents compared to the NS basalts (Fig. 2). A diagram of K/ $\mathrm{Yb}$ against $\mathrm{Nb} / \mathrm{Yb}$ (Fig. 12) is informative in regard to the causes of relative enrichment and depletion in incompatible elements (Pearce et al., 1995). The OS and NS magmas have similar K/ $\mathrm{Yb}$ ratios but distinct $\mathrm{Nb} / \mathrm{Yb}$ ratios, which suggests that they were produced from a variably enriched mantle source modified by addition of a constant subduction component. As the magma associated with the high- $\mathrm{NiO}$ olivines was present only during OS activity, it may be reasonable to assume that it was the cause of variations in geochemistry and therefore that it was depleted in HFSE compared to the melt associated with the low-NiO olivines (present during both OS and NS activity). This relative depletion would reflect a less enriched source, which is consistent with the mineralogical data presented above.

In summary, We propose the following model to account for the variations in chemistry of the spinel inclusions and their olivine hosts in the OS and NS basalts (Fig. 13): OS basalts resulted from mixing between two parental magmas produced from contrasted sources; a relatively depleted and $\mathrm{H}_{2} \mathrm{O}$-poor harzburgite and a less depleted and more hydrated harzburgite to lherzolite, whereas the NS basalts were produced from the less depleted and hydrated source only.

\subsection{Magmatic processes}

Phenocrysts crystallising in a melt retain a record of changes in ambient conditions during their growth. Consequently, they provide an insight into the dynamics of the magmatic system during a particular period of activity. In the four studied samples, the large range of olivine compositions combined with the presence of plagioclase and pyroxene provide a useful data set in order to place constrain on the path of evolution of the Slamet basalts. The contrasted populations of olivine, and the distinctive zoning patterns displayed by the olivine, plagioclase and pyroxene indicate that the OS and NS magmas underwent contrasted magmatic evolution.

\subsubsection{OS magmatic system}

As discussed above, the OS basalts appear to have resulted from mixing of two parental magmas with distinct olivine groups in terms of $\mathrm{NiO}$ content. Therefore, the homogenous distribution of Fo content observed for the olivine of these samples (Fig. 4a,b) cannot be regarded as indicative of a simple 'along a liquid line of descent' crystallisation history. Rather, it indicates that the two liquids, when they mixed, were relatively similar in terms of $\mathrm{Mg \#}$. Nevertheless, the presence of high-Fo olivine and high $\mathrm{Mg \#}$ pyroxene not in equilibrium with a melt similar to the host whole-rock composition (Figs. 4a,b and 10), as well as the presence of reversely zoned pyroxene suggest that one of the parental magmas had a slightly higher $\mathrm{Mg \#}$ than the other when they 


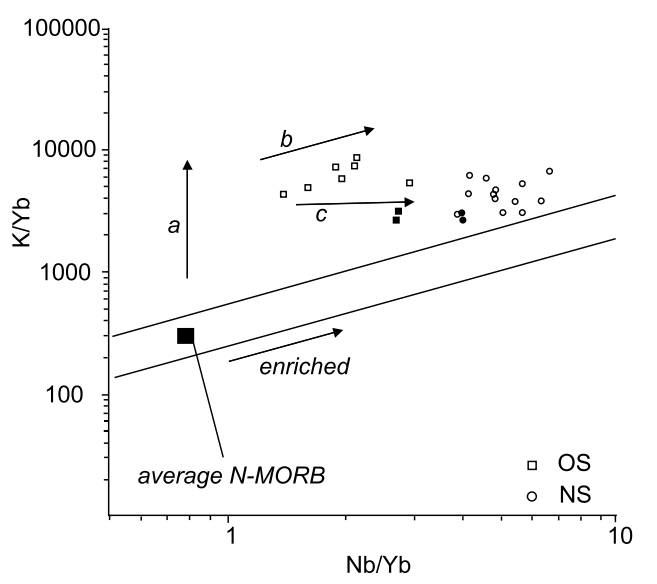

Fig. 12. $\mathrm{K} / \mathrm{Yb}$ vs $\mathrm{Nb} / \mathrm{Yb}$ for Slamet basalts. Open symbols data from Vukadinovic (1989). Filled symbols are data from this study. Trend a: variable addition of a subduction component to a mantle wedge of constant composition. Trend $b$ : dynamic melting following addition of the subduction component. Trend $\mathrm{c}$ : addition of a constant subduction component to a variably enriched mantle wedge (Pearce et al., 1995).

mixed. The dominant form of zoning for the plagioclase and pyroxene is oscillatory zoning that is accompanied by minor change in composition. Most of the concentric sieved zones observed within plagioclase are not associated with large changes in $\mathrm{An} \%$. This suggests that cyclic changes in volatile content and/or temperature were prevalent in the OS magmatic system. This may result from convection in a magma chamber with a significant gradient in terms of temperature or/and volatile content or from repetitive input of mafic $\mathrm{H}_{2} \mathrm{O}$-rich magma into a constantly degassing chamber. We favour this second hypothesis as it is consistent with the occurrence of mixing discussed earlier. However, these events are directly recorded (reverse zoning associated with large variation in composition) only by few crystals, which implies that they were localised. Melt inclusions are commonly trapped during rapid growth (Roedder, 1984); hence the near-constant compositions, $\sim \mathrm{Fo}_{75}$ of cores rich in melt inclusions in Type 2 olivines, suggest that they reflect a period of rapid crystallisation due to either rapid cooling or decrease in $\mathrm{pH}_{2} \mathrm{O}$ at shallow level. Such an event may also have contributed to produce the large range of Fo content.
In summary, the OS magmatic system was characterised by mixing between two parental magmas distinct in terms of composition but similar in regard to their limited degree of crystal fractionation (Fig. 13a). Within the magma chamber, variations in volatile content and/or temperature were predominant or at least had more impact on the crystallising phases than mixing. The variations in volatile content and/or temperature could possibly have been due to intermittent input of batches of $\mathrm{H}_{2} \mathrm{O}$-rich parental melt and degassing in a magma chamber originally dominated by the $\mathrm{H}_{2} \mathrm{O}$-poor parental melt.

\subsubsection{NS magmatic system}

The NS basalts evolved from a single parental melt, but their discontinuous distributions of olivine Fo content (Fig. 4c,d) as well as the presence of pyroxenes clearly in disequilibrium with a whole-rock like melt indicate that mixing between two melts and/or crystal populations occurred. The Fe-rich olivine, the orthopyroxene and the clinopyroxene which displays resorption textures are all in equilibrium with a liquid with $\mathrm{Mg \#} \sim 35$ (using $\quad{ }^{\mathrm{Fe}} / \mathrm{Mg} K_{\mathrm{D} \text { olivine } / \text { melt }}=0.3$ and $\mathrm{Fe} / \mathrm{Mg} K_{\mathrm{D} \text { pyroxene } / \text { melt }}=0.26$; Roeder and Emslie, 1970; Sisson and Grove, 1993), which signifies that they were in equilibrium with an evolved melt, probably andesitic in composition. All these crystals display reverse zoning associated with resorption textures, clearly indicating that they were incorporated into a more mafic liquid. The relatively magnesian compositions of the rims of these crystals, which are close to equilibrium with a whole-rock like melt, along with the absence of textural indications of magma mixing in these rocks, indicate that these crystals were incorporated into the basaltic melt without being accompanied by a significant volume of andesitic magma. The presence of reversely zoned Type 2 olivines suggest that part of these crystals underwent a period of rapid cooling or decrease in $\mathrm{pH}_{2} \mathrm{O}$ at shallow level prior to magma mixing. Consequently, we interpret these crystals as representing an older crystal mush formed in an andesitic melt that was disaggregated and incorporated into a basaltic liquid.

Interestingly, only basaltic lavas are known to 
a) Old Slamet basalts

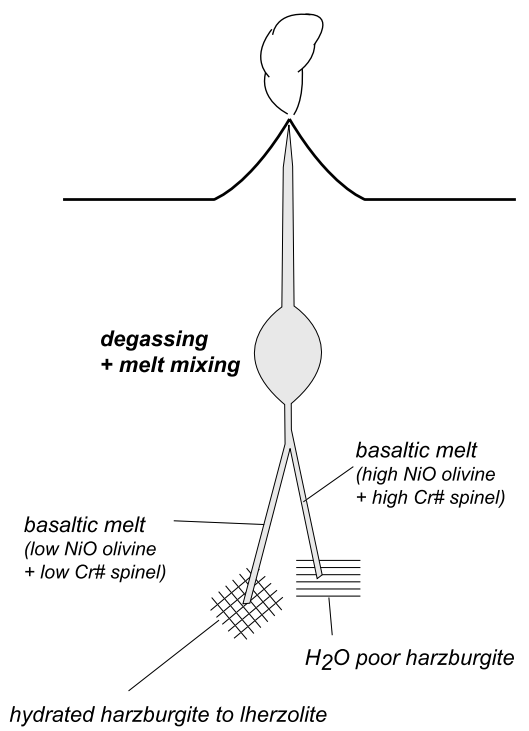

b) New Slamet basalts

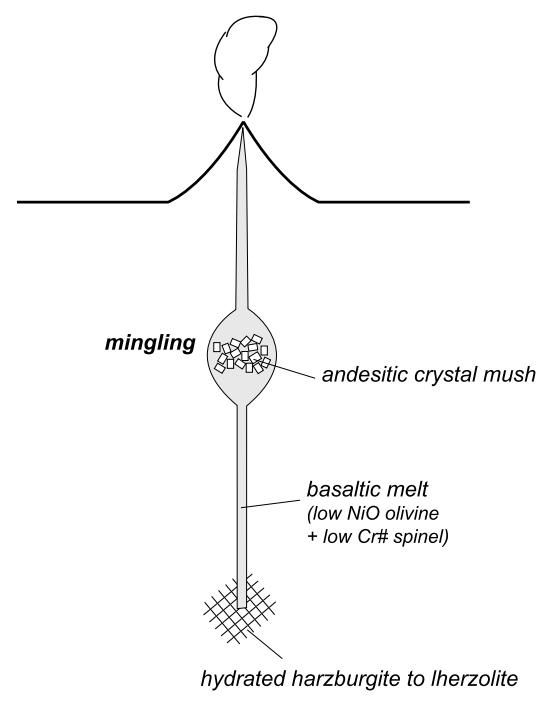

Fig. 13. Schematic cartoon of the suggested model of genesis and evolution of the OS and NS basalts (see text for discussion).

have been erupted during the NS activity (Vukadinovic, 1989). The resorbed crystals could therefore indicate that andesitic melts were produced but never reached the surface or more probably that old crystal mush left behind during previous activity was remobilised by the NS basaltic magmas. We conclude that younger basaltic melts reactivated and partially flushed the magmatic conduits formed during previous activity. Such a process is expected to limit the amount of crustal contamination, which is in agreement with the lower ${ }^{87} \mathrm{Sr} /{ }^{86} \mathrm{Sr}$ ratios of the NS basalts compared to the OS basalts (Vukadinovic and Nicholls, 1989). High clinopyroxene content and low plagioclase content suggest higher $\mathrm{H}_{2} \mathrm{O}$ content than in the OS magmas (Sisson and Grove, 1993), which is consistent with the hypothesis that they were produced from the $\mathrm{H}_{2} \mathrm{O}$-rich parental melt.

In summary, the NS magmatic system was characterised by evolution from a single primary magma (Fig. 13b). Subsequent extensive interaction between fresh basaltic magma and old andesitic crystal mush/magma left behind during previous magma transport was a ubiquitous feature during the NS volcanic activity.

\section{Conclusions}

The complex and variable patterns shown by the mineralogy of the four studied basalts demonstrate that open-system processes occurred early in the evolution of the Slamet basaltic magmas. In particular, mixing either between two contrasted parental magmas or between variably fractionated melts/crystal mush appears to have been an ubiquitous process during the evolution of these basaltic magmas. Identification of the second type of mixing is relatively easy due to pervasive disequilibrium textures shown by the crystals involved. However recognition of the first type of mixing may be difficult on the basis of a petrographic study only and requires detailed mineralogical analyses. The early occurrence of open-system processes imply that models that address mantle processes such as the composition of the source, the nature and the composition of the component derived from the subducted slab, and the degree of partial melting on the basis of whole-rock geochemical data should be treated with caution even for these relatively $\mathrm{Mg}$-rich basalts. 
The mineralogy of the spinel inclusions and their olivine hosts indicate that two distinct sources, probably a relatively depleted and $\mathrm{H}_{2} \mathrm{O}$-poor harzburgite and a less depleted and more hydrated harzburgite to lherzolite were involved during OS activity whereas only the less depleted and more hydrated source was involved during NS activity. These variations, in particular the $\mathrm{H}_{2} \mathrm{O}$ content of the mantle and consequently of the primary magmas, controlled the compositions and the modal proportions of the crystallising phases and therefore the fractionation path of the primary magmas. The contrasted patterns recorded by the phenocrysts in the NS and OS basalts suggest that the dynamics of the magmatic system changed significantly over the life of Slamet Volcano. Even if this cannot be clearly demonstrated it is expected that the variations in the source, in particular the amount of water as well as some related parameters such as the amount of melt produced played a significant role in these variations.

The variable zoning patterns and textures displayed by individual crystals of particular minerals, or between various minerals in each sample, clearly demonstrate that these basalts represent a blend of crystals that have experienced different growth conditions either in a single melt or in distinct melts that have been subsequently mixed. Magma mixing was a ubiquitous process in this system and controlled, together with fractional crystallisation, the evolution of the basaltic magmas at Slamet Volcano from the early stages of magmatism.

\section{Acknowledgements}

We thank Alexander Priymak for help with the microprobe, and James Brophy and John Foden for constructive reviews.

\section{References}

Arai, S., 1987. An estimation of the least depleted spinel peridotite on the basis of olivine-spinel mantle array. Neues Jahrb. Mineral. Mon.schr., 347-354.

Arai, S., 1992. Chemistry of chromian spinel in volcanic rocks as a potential guide to magma chemistry. Mineral. Mag. 56, 173-184.

Arculus, R.J., 1994. Aspects of magma genesis in arcs. Lithos 33, 189-208.

Baker, M.B., Stolper, E.M., 1994. Determining the composition of high-pressure mantle melts using diamond aggregates. Geochim. Cosmochim. Acta 58, 2811-2827.

Ballhaus, C., Berry, R.F., Green, D.H., 1991. High pressure experimental calibration of the olivine-orthopyroxene-spinel oxygen geobarometer: implications for the oxidation state of the upper mantle. Contrib. Mineral. Petrol. 107, 27-40.

Blundy, J.D., Brodholt, J.P., Wood, B.J., 1991. Carbon-fluid equilibria and the oxidation state of the upper mantle. Nature 349, 321-324.

Clynne, A., Borg, L.S., 1997. Olivine and chromian spinel in primitive calc-alkaline and tholeiitic lavas from the southernmost Cascade Range, California: A reflection of relative fertility of the source. Can. Mineral. 35, 453-472.

Curray, J.R., Emmel, F.J., Moore, D.G., Raitt, R.W., 1982. Structure, tectonics and geological history of the northeastern Indian Ocean. In: Nairn, Stehli, F.G. (Eds.), The Ocean Basins and Margins. Ocean. Plenum Press, New York, pp. 399-450.

Dick, H.J.B., Bullen, T.D., 1984. Chromian spinel as a petrogenetic indicator in abyssal and alpine-type peridotites and spatially associated lavas. Contrib. Mineral. Petrol. 86, 54 76.

Dick, H.J.B., Fisher, R.L., 1984. Mineralogic studies of the residues of mantle melting: abyssal and alpine-type peridotites. In: Kornprobst, J. (Ed.), Kimberlites II. The Mantle and Crust-Mantle Relationships. Elsevier, Amsterdam, pp. 295-308

Dungan, M.A., Wulff, A., Thompson, R., 2001. Eruptive stratigraphy of the Tatara-San Pedro Complex, $36^{\circ} \mathrm{S}$, southern volcanic zone, Chilean Andes: reconstruction method and implications for magma evolution at long-lived arc volcanic centers. J. Petrol. 42, 555-626.

Falloon, J., Danyushevsky, L.V., 2000. Melting of refractory mantle at 1.5 and $2.5 \mathrm{GPa}$ under anhydrous and $\mathrm{H}_{2} \mathrm{O}$ undersaturated conditions: Implications for the petrogenesis of high-Ca boninites and the influence of subduction components on mantle melting. J. Petrol. 41, 257-284.

Feeley, T.C., Dungan, M.A., 1996. Compositional and dynamic controls on mafic-silicic magma interactions at continental arc volcanoes: Evidence from Cordon El Guadal, TataraSan Pedro Complex, Chile. J. Petrol. 37, 1547-1577.

Gamble, J.A., Wood, C.P., Price, R.C., Smith, I.E.M., Stewart, R.B., Waight, T., 1999. A fifty year perspective of magmatic evolution on Ruapehu Volcano, New Zealand: verification of open system behaviour in an arc volcano. Earth Planet. Sci. Lett. 170, 301-314.

Hamilton, W.R., 1979. Tectonics of the Indonesian Region, 345 pp.

Hirose, K., Kushiro, I., 1993. Partial melting of dry peridotites at high pressures: Determination of composition of melts segregated from peridotite using aggregates of diamond. Earth Planet. Sci. Lett. 114, 477-489. 
Jaques, A.L., Green, D.H., 1980. Anhydrous melting of peridotite at $0-15 \mathrm{~kb}$ pressure and the genesis of tholeiitic basalts. Contrib. Mineral. Petrol. 73, 287-310.

Kamenetsky, V.S., Crawford, A.J., Meffre, S., 2001. Factors controlling chemistry of magmatic spinel: an empirical study of associated olivine, $\mathrm{Cr}$-spinel and melt inclusions from primitive rocks. J. Petrol. 42, 655-671.

Kinzler, J.R., Grove, T.L., Recca, S.I., 1990. An experimental study of the effect of temperature and melt composition on the partitioning of nickel between olivine and silicate melt. Geochim. Cosmochim. Acta 54, 1255-1265.

Osborn, E.F., 1959. Role of oxygen pressure in the crystallization and differentiation of basaltic magma. Am. J. Sci. 257, 609-647.

Panjasawatwong, Y., Danyushevsky, L.V., Crawford, A.J., Harris, K.L., 1995. An experimental study of the effect of melt composition on plagioclase-melt equilibria at 5 and 10 Kbar: implications for the origin of magmatic high-An plagioclase. Contrib. Mineral. Petrol. 118, 420-432.

Pearce, J.A., Peate, D.W., 1995. Tectonic implications of the composition of volcanic arc magmas. Annu. Rev. Earth Planet. Sci. 23, 251-285.

Pearce, J.A., Baker, P.E., Harvey, P.K., Luff, I.W., 1995. Geochemical evidence for subduction fluxes, mantle melting and fractional crystallisation beneath the South Sandwich island arc. J. Petrol. 36, 1073-1109.

Pearce, T.H., Kolisnik, A.M., 1990. Observation of plagioclase zoning using interference imaging. Earth Sci. Rev. 29, 9-26.

Peccerillo, A., Taylor, S.R., 1976. Geochemistry of Eocene calc-alkaline volcanic rocks from the Kastamonu area, northern Turkey. Contrib. Mineral. Petrol. 58, 63-81.

Roedder, E., 1984. Fluid inclusions. Reviews in Mineralogy. Mineral. Soc. Am. 12, 1-644.

Roeder, P.L., Emslie, R.F., 1970. Olivine-liquid equilibrium. Contrib. Mineral. Petrol. 29, 275-289.

Roeder, P.L., Reynolds, I., 1991. Crystallization of chromite and chromium solubility in basaltic melts. J. Petrol. 32, 909934.
Singer, B.S., Dungan, M.A., Layne, G.D., 1995. Textures and $\mathrm{Sr}, \mathrm{Ba}, \mathrm{Mg}, \mathrm{Fe}, \mathrm{K}$ and $\mathrm{Ti}$ compositional profiles in volcanic plagioclase: Clues to the dynamics of calc-alkaline magma chambers. Am. Mineral. 80, 776-798.

Sisson, T.W., Grove, T.L., 1993. Experimental investigations of the role of $\mathrm{H}_{2} \mathrm{O}$ in calc-alkaline differentiation and subduction zone magmatism. Contrib. Mineral. Petrol. 113, 143-166.

Sun, S.S., McDonough, W.F., 1989. Chemical and isotopic systematics of oceanic basalts: implications for mantle composition and processes. In: Saunders, A.D., Norry, M.J. (Eds.), Magmatism in the Ocean Basins. Geol. Soc. Spec. Publ. 42, pp. 313-445.

Sutawidjaja, I.S., Aswin, D., Sitorus, K., 1985. Geological map of Slamet volcano, Central Java. Volcanological Survey of Indonesia.

Tepley, F.J., III, Davidson, J.P., Tilling, R.I., Arth, J.G., 2000. Magma mixing, recharge and eruption histories recorded in plagioclase phenocrysts from El Chichon Volcano, Mexico. J. Petrol. 41, 1397-1411.

Tsuchiyama, A., 1985. Dissolution kinetics of plagioclase in the melt of the system diopside-albite-anorthite, and the origin of dusty plagioclase in andesites. Contrib. Mineral. Petrol. $89,1-16$.

Ulmer, P., 1989. The dependence of the $\mathrm{Fe}^{2+}-\mathrm{Mg}$ cation partitioning between olivine and basaltic liquid on pressure, temperature and composition: an experimental study to 39 kbars. Contrib. Mineral. Petrol. 101, 261-273.

Vukadinovic, D., 1989. Petrology and Geochemistry of Gunung Slamet Volcano, Central Java, Indonesia. PhD Thesis, Monash University, Melbourne, 268 pp.

Vukadinovic, D., Nicholls, I.A., 1989. The petrogenesis of island arc basalts from Gunung Slamet volcano, Indonesia: Trace element and ${ }^{87} \mathrm{Sr} /{ }^{86} \mathrm{Sr}$ constraints. Geochim. Cosmochim. Acta. 53, 2349-2363.

Whitford, D.J., 1975. Geochemistry and Petrology of Volcanic Rocks from the Sunda Arc, Indonesia. PhD Thesis, Australian National University, Canberra, 449 pp. 